\title{
Review \\ Uptake and Dissemination of Multi-Criteria Decision Support Methods in Civil Engineering-Lessons from the Literature
}

\author{
Michael Bruen
}

Citation: Bruen, M. Uptake and Dissemination of Multi-Criteria Decision Support Methods in Civil Engineering-Lessons from the Literature. Appl. Sci. 2021, 11, 2940. https://doi.org/10.3390/app11072940

Academic Editor: Claudio Guarnaccia

Received: 5 February 2021

Accepted: 22 March 2021

Published: 25 March 2021

Publisher's Note: MDPI stays neutral with regard to jurisdictional claims in published maps and institutional affiliations.

Copyright: (C) 2021 by the author. Licensee MDPI, Basel, Switzerland. This article is an open access article distributed under the terms and conditions of the Creative Commons Attribution (CC BY) license (https:// creativecommons.org/licenses/by/ $4.0 /)$.
School of Civil Engineering, University College Dublin, Belfield, Dublin 4, Ireland; michael.bruen@ucd.ie

\begin{abstract}
The SCOPUS and Wed of Science bibliometric databases were searched for papers related to the use of multi-criteria methods in civil engineering related disciplines. The results were analyzed for information on the reported geographical distribution of usage, the methods used, the application areas with most usage and the software tools used. There was a wide geographical distribution of usage with all northern hemisphere continents well represented. However, of the very many methods available, a small number seemed to dominate usage, with the Analytic Hierarchy Process being the most frequently used. The application areas represented in the documents found was not widely spread and mainly seemed to be focused on issues such as sustainability, environment, risk, safety and to some extent project management, with less usage on other areas. This may be due to individual engineer's choices in relation to if and how to disseminate the results of their work and to their choice of keywords and titles that determine if their publications are selected in bibliographic searches and thus more visible to a wider readership. A comparison with more topic focused searches, relating to Bridge Design, Earthquake Engineering, Cladding, Sewage Treatment, Foundation design, Truss design, Water Supply, Building Energy, Route selection and Transport mode showed very different results. Analysis of the papers in this area indicated that the full range of supporting software available for multi-criteria decision analysis (many listed in this paper) may not be fully appreciated by potential users.
\end{abstract}

Keywords: multi-criteria; decision support; MCDA; civil engineering; bibliographic survey; software; dissemination

\section{Introduction}

Multi-criteria decision analysis (MCDA) is used in a wide variety of decision support applications. In keeping with the theme of this Special Issue, the hypothesis examined in this paper is that such methods are underutilized in the disciplines normally associated with civil engineering, i.e., those relating to structures, transportation, geotechnics, environment, water, and waste. This may be because information about the potential of these methods and about the tools available to implement them is not as widely known amongst practicing engineers, suggesting a communications lacuna. In this regard, the published technical literature is an important communications channel and here we investigate whether its use in disseminating information on MCDA can be improved. The methodology is to undertake a series of searches and reviews of the published literature relating to the use of MCDA in these disciplines and to address the hypothesis by analyzing the number and patterns of documents emerging from the different searches. The paper begins with (i) a short concise introduction setting out the background to MCDA, and (ii) a summary of previous surveys or comparisons of some MCDA methods related to civil engineering. Then, the main contribution of this paper follows in three further sections; (iii) a description of the methodology used in the literature review followed by (iv) a detailed analysis and discussion of the results, (v) a short description of MCDA software and (vi) a summary of the conclusions arising from this analysis.

This analysis is motivated, in part, by the realization that, not only should the engineer make good and appropriate design choices, but that she or he should be able to explain 
and justify those choices to (i) other professionals, (ii) project funders and increasingly to (iii) the legal profession when there are court challenges to the choices made, and (iv) to the general public, particularly where environmental, health and safety matters are concerned. In situations where many factors, both quantitative and qualitative, must be considered, systematic MCDA methods that are well regarded and algorithmically sound are becoming essential for this purpose. Thus, it is essential that civil engineers are familiar with the key methods and tools and this is assessed here based on technical publications on this topic.

\section{Background}

In planning large infrastructure projects, engineers are often faced with discrete, multicriteria decision or choice problems. These arise when there are $n$ feasible options $\left(a_{1}, a_{2}\right.$, $\left.\ldots, a_{n}\right)$ each of which must be assessed on $m$ criteria $\left(c_{1}, c_{2}, \ldots, c_{m}\right)$, typically related to cost, performance, sustainability, environmental impact, reliability, aesthetic value, expandability, risk, health, safety, etc. A two dimensional (n by $\mathrm{m}$ ) array of assessments can be generated, in which each element, $s_{i, j}$, contains the assessment of option $a_{i}$ for criterion $c_{j}$. Sometimes, all $s_{i, j}$ elements of the array are numbers but this is not always the case and some criteria are more naturally assessed qualitatively, for instance aesthetic value. Many methods have been developed to support decision making based on the information in this array of assessments. One way of classifying these methods is:

"Compensatory analysis methods" [1] that produce a single score for each decision or design option so they can be ranked, or at least the best or a set of better options can be identified. The principal differences between the methods in this category are mainly on how the assessment information is used to generate the single score for each option and in what additional information is required for this, e.g., importance weights and how such information is obtained. Such methods reduce all aspects of the problem to a single one-dimensional index or score, usually financial, i.e., related to costs, or to the concept of utility [2] or some other index, that, for each option, that combines its performance under all the criteria and allows options to be directly compared. In these methods, the performance of a particular design option or choice evaluated for each of the criteria are effectively traded-off amongst each other., i.e., a bad performance in one criterion can be offset by good performances in other criteria. The type of trade-off is common for all the compensatory methods and these include cost-benefit analysis (CBA) [3], simple additive weighting (SAW) [4], multi-attribute utility theory (MAUT) [5], the Analytic Hierarchy Process (AHP) [6] and the Technique for Order of Preference by Similarity to Ideal Solution (TOPSIS) [7].

In contrast, "non-compensatory methods" [8], sometimes called "outranking methods" focus on the options and do a series of individual comparisons of pairs of options to determine, from the assessment array, whether one of them is better, worse, or equivalent to the other. This is done for all possible pairs of options, producing a matrix of outranking relationships which can be used to select options. The approach maintains the multi-dimensionality of the criteria and allows them to influence the final choice or ranking of option(s) without an explicit trade-off of one criterion against another. Concordance-Discordance based methods such as the various forms of ELECTRE $[9,10]$ and PROMETHEE [11] are examples of the second group, and there are a number of other methods following a similar approach [12]. The important difference between this and the first group is there is no explicit trading-off or ranking of the importance of the individual criteria.

The third category is "other" methods that do not fit neatly into either of the first two categories, such as decision-rule-based techniques [13]. These tend to be less widely used than the first two groups so will not be discussed further here.

The technical details of the individual methods are not described here, and, for these, the reader is referred to the key citations listed above and in Table 1. Instead, their use in practice is inferred from a search of published literature, described below. Note that fuzzy number versions of many of these methods have been developed. 
Table 1. Key methods discussed in this paper (with abbreviations).

\begin{tabular}{|c|c|c|c|}
\hline Abbreviation & Name & Citation & Category \\
\hline AHP & Analytic Hierarchy Process & [6] & compensatory \\
\hline ANP & Analytic Network Process & [14] & compensatory \\
\hline CBA & Cost Benefit Analysis & [15] & compensatory \\
\hline COPRAS & Complex Proportional Assessment & [16] & compensatory \\
\hline CRITIC & $\begin{array}{l}\text { Objective assessment of weights } \\
\text { for MCDA }\end{array}$ & [17] & weights only \\
\hline ELECTRE & $\begin{array}{l}\text { ELimination Et Choix } \\
\text { Traduisant la REalité }\end{array}$ & [10] & $\begin{array}{l}\text { non-compensatory } \\
\text { outranking }\end{array}$ \\
\hline MACBETH & $\begin{array}{l}\text { Measuring Attractiveness by a } \\
\text { Categorical Based Evaluation Technique }\end{array}$ & [18] & compensatory \\
\hline MAUT & Multi-Attribute Utility Theory & [5] & multi-dimensional function \\
\hline MAVT & Multi-Attribute Value Theory & [19] & multi-dimensional function \\
\hline MOORA & $\begin{array}{l}\text { Multi-Objective optimization on the basis } \\
\text { of ratio analysis }\end{array}$ & {$[20]$} & compensatory \\
\hline PROMETHEE & $\begin{array}{l}\text { Preference Ranking Organization Method } \\
\text { for Enrichment Evaluation }\end{array}$ & [11] & $\begin{array}{l}\text { non-compensatory } \\
\text { outranking }\end{array}$ \\
\hline SAW or WAS & Simple Additive Weighting & [4] & compensatory \\
\hline Simos' cards & $\begin{array}{l}\text { Method for eliciting cardinal information } \\
\text { on preferences from stakeholders }\end{array}$ & [21] & weights only \\
\hline TOPSIS & $\begin{array}{l}\text { Technique for Order Preference by } \\
\text { similarity to Ideal Solution }\end{array}$ & [7] & compensatory \\
\hline VIKOR & $\begin{array}{c}\text { Visekriterijumsko Kompromisino } \\
\text { Rangiranje (Serbian) }\end{array}$ & [22] & compensatory \\
\hline
\end{tabular}

It is interesting to consider what each approach assumes about the preferences and internal decision processes of the decision maker(s) and which represents these best. Many of the compensatory methods used weighted averages and thus assume that the "value" the decision maker places on a certain level of any criterion is independent of the levels of the other criteria. This is an essential requirement for the method justifying adding together the individual, scaled, impacts of all criteria. However, a human decision maker does not always make a decision in this way, [23]. Of the compensatory methods, MAUT is an exception to direct weighted sums as it uses a multi-dimensional utility function in which the level of one criterion can influence the impact of other criteria. However, the complexity of forming this multidimensional function and the information required to implement in practice limits the number of criteria that can be reasonably managed, although there are techniques for mitigating this limitation [24]. Compensatory methods also imply that a very good performance in one criterion can compensate for a very poor performance in another and the weights used should be interpreted as trade-off coefficients. On the other hand, non-compensatory methods do not make this assumption, and most will take account of the criteria for which an option performs poorly as well as those for which it performs well. The weights used can be interpreted as importance indicators, [25]. Non-compensatory methods often involve thresholds of acceptability and building an outranking relationship, see Figure 1. 


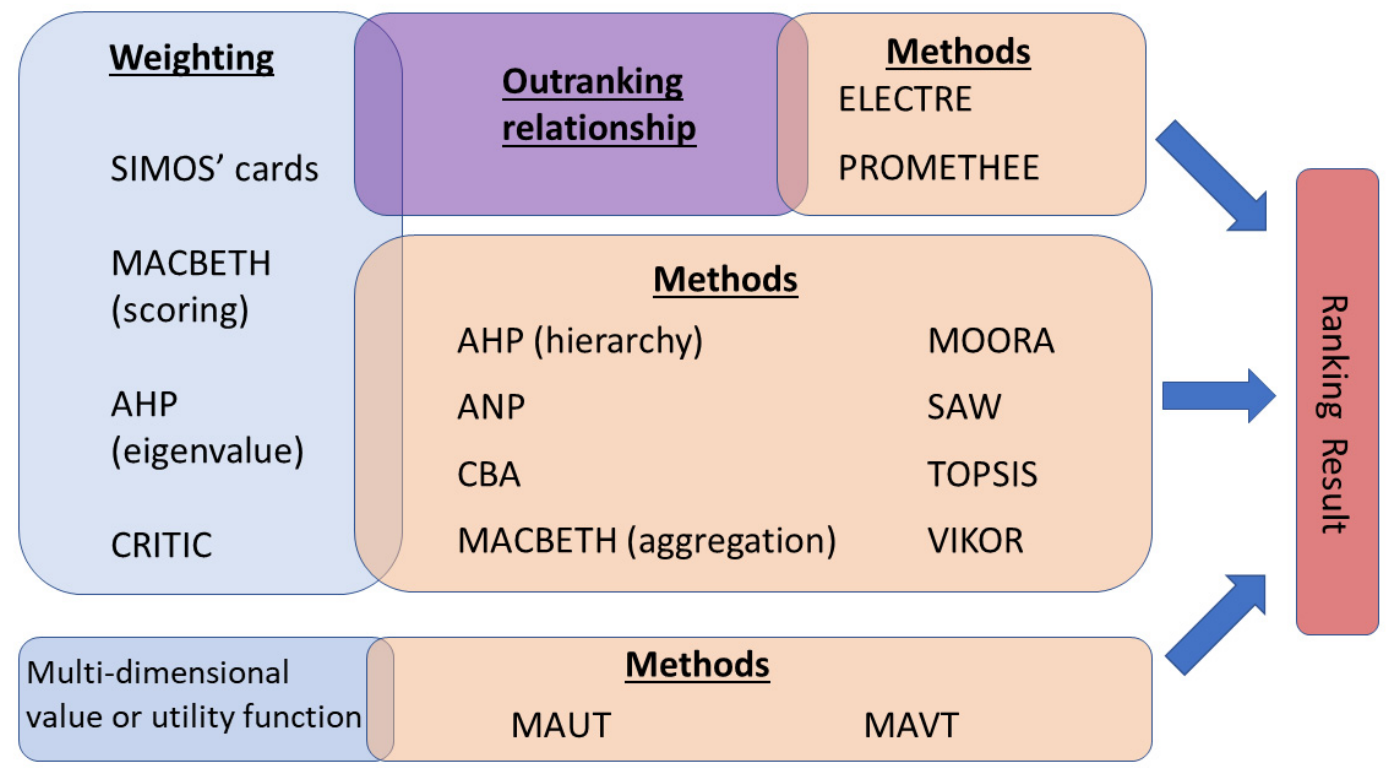

Figure 1. Grouping of multi-criteria decision analysis (MCDA) techniques and components. (Note: citations for all terms in the figure are listed in Table 1. Fuzzy number versions of some of these methods have been developed).

Most engineering design or decision problems require either ranking or choosing from a range of feasible options and so can be addressed by either method, depending on the supporting information available [26]. Often the complexity of the problem and the amount of information that must be considered require a computational approach, typically a software implementation of one of the MCDA methods listed above. This paper examines the published technical literature to see the development of the main methods and to critically examine the wide range of their applications in civil and environmental engineering practice.

\section{Previous Work}

A taxonomy of general approaches to MCDA has been developed by [27] that includes (a) how the decision problem is formulated, (b) how criteria are established, and (c) how stakeholder preferences are determined and implemented. Here, we are concerned only with (c) the implementation methodologies. There are many reviews of these methods in the published literature, but few specifically focused on civil engineering applications, for example [28], and some on environmental decisions, e.g., [1]. However, there are few published comparisons of methods in design and management contexts, that compare more than two methods. One example is [29] that lists 33 papers describing applications in (i) architecture, (ii) urban planning and (iii) energy-efficient construction which were the keywords in her literature review. While 17 methods were mentioned in the papers reviewed, AHP was used 16 times, much more than any of the other methods. Examples of some limited comparisons are, [26] who compared PROMETHEE, TOPSIS, VIKOR and COPRA and [30] who compared AHP, TOPSIS and VIKOR and preferred VIKOR for the selection of a manufacturing process. Four methods were compared by [31] for use in Life Cycle Assessment applications, and three (AHP, TOPSIS and a fuzzy logical based method due to Mamdani) gave comparable results. The AHP, TOPSIS and SAW (simple additive weighting) methods were applied by [32] to the operation of a rubber plantation and AHP was preferred. Preferences of 40 MCDA users were explored by [33], but only with three methods, all of which had similar evaluations. In a power generation application, [34] compared SAW, AHP, TOPSIS and a multiplicative method, all of which produced similar results. Some of the issues arising in comparison of decision support methods are discussed by [35], while the most general intercomparison of MCDA methods found in the literature search was by [36] who assessed the users experience and difficulties with methods as well as comparing their results. 
Thus, few recent extensive comparisons of a wide range of MCDA methods in civil engineering or related applications were found that might give guidance on the selection of suitable methods, except for [28], and none describing the software available for a wide range of applications related to civil engineering. This is understandable, given the widely different data requires of many of the methods, that would make an objective comparison difficult. However, there are substantive reviews focused on specific aspects of Civil Engineering, such as [37] in relation to sustainability in Bridge Design, or [29] in relation to energy efficient building design. Therefore, for this paper, an alternative way to explore the usefulness of MCDA methods is to assess published information on their usage in civil engineering practice to determine the most widely used methods and the application areas in which they are used. Thus, a focused review of the literature was undertaken for this paper, as described below.

\section{Methodology of Literature Review}

Two large bibliometric databases, Scopus (an abstract and citation database curated by Elsevier) and Web of Science (also an abstract and citation database covering a wide range of disciplines, curated by Clarivate Analytics), were searched for relevant publications, using the following complex search criterion:

("multi criteria" OR "multi-criteria" OR "multi criterion" OR "multi-criterion")

and

("Civil Engineering" OR "structural engineering" OR "municipal engineering" OR

"highway engineering" OR "transportation engineering" OR "geotechnical engineering"

$O R$ "water engineering" $O R$ "water resources engineering")

In the first component of the query, various possible combinations of the words multiand criterion or criteria were included to take account of possible variations between authors with different approaches to hyphenation or to the use of the Latin version of the plural. This component was applied only to keywords in the database to ensure that MCDA was a significant topic on any selected publication. The second component of the query combined the traditional terms used to describe the branches of engineering, all part of civil engineering, to be searched. This was necessary as often the general term "civil engineering" was not always given as a keyword with all relevant papers and more specific terms were used, e.g., transportation or geotechnical. The second part of the search was applied to the title and abstract of the documents as well as to their keywords. The search of Scopus returned 184 documents published between 1990 and 2021. The corresponding search of Web of Science returned 315 documents. The results were combined (removing duplicates) to give a combined database with 486 documents with publication dates between 1990 and 2021. It was surprising that there were only 13 duplicates. Although SCOPUS is focused on the content of Elsevier journals, it was expected that a far larger fraction of these would also be listed in the search of the Web of Science database. The strong implication is that, when undertaking a literature review, multiple databases should be searched as the results can be very different.

\section{Analysis of Results}

\subsection{Basic Statistics}

The database of 486 references was analyzed in detail using the $\mathrm{R}$ "Bibliometrix" package [38]. There were more journal articles (254) than conference or proceedings papers (185) together with a small number of reviews (15) and some books (24) and book chapters (4). There was a relatively low average of 1.34 citations per year per document, partly explained by the relatively high fraction of conference papers in the collection, since conference papers tend to have fewer citations [39]. The publication rate over time shows considerable variation from year to year, but with a generally rising trend since about 2003, Figure 2, and a peak of almost 80 documents in 2019 — the search was conducted in 2020 so results for that year were incomplete. This is consistent with the statement in the 
Introduction that, for many reasons, MCDM is becoming an increasingly essential tool for the civil engineer.

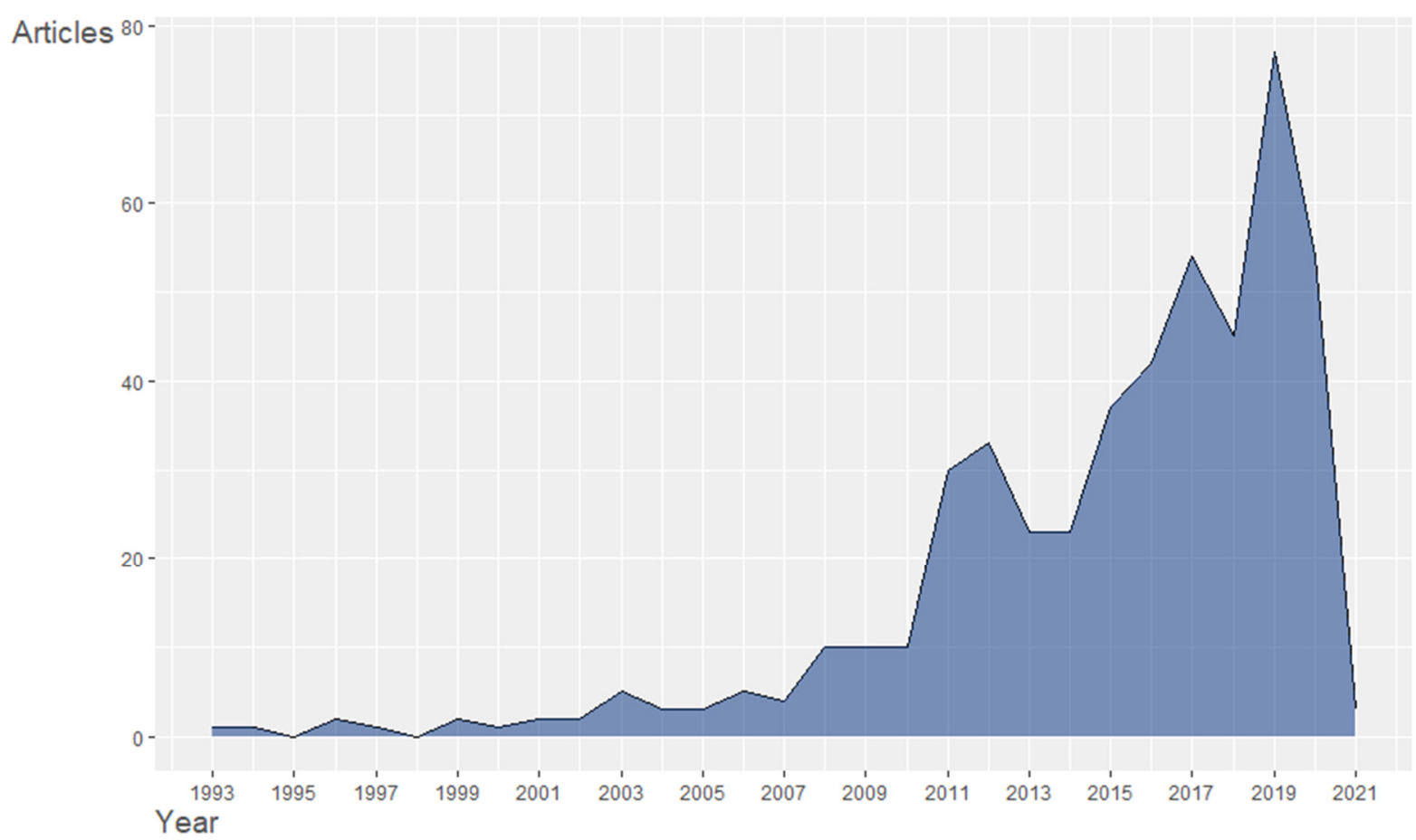

Figure 2. MCDA documents related to civil engineering-publication rates (per annum) over time.

\subsection{Most Active Geographical Regions}

As might be expected, Asia (China, India and Korea), North America (USA and Canada) and Europe (Poland, Lithuania, Italy, Spain Czech Republic and France) are the continents dominating the top countries of corresponding authors, reflecting the large amount of infrastructure and/or development in these regions, Figure 3. In this Figure each horizontal bar is divided into green and red sections indicating the proportion of papers from the country for which there are co-authors from other countries (red) or the proportion of those in which all co-authors were from the same country (green). Most of the documents were multi-authored, with an average of 2.8 authors per document and only 63 (i.e., 13\%) were single authored documents. This is consistent with the MCDA analysis reported in the paper being a single part of a much larger project with many contributors.

The national distribution of authors shows quite a variation shown by the colours in Figure 3. For instance, some papers from China, Canada, Poland, Lithuania, Spain, and Iran have multinational mixes of co-authors while the co-authors of papers from some other countries (USA, India, Czech Republic, and Turkey) tend to be from the same country.

Some countries, such as Lithuania (population 2.7 Million) and Italy (population 60 Million) have a considerably higher number of contributions when considered as a proportion of their population (e.g., Lithuania 8.9 articles per Million population, and Italy 0.33 articles per Million) when compared to much larger countries, e.g., China (0.04) or India (0.015). In between these extremes is the USA (0.15). 


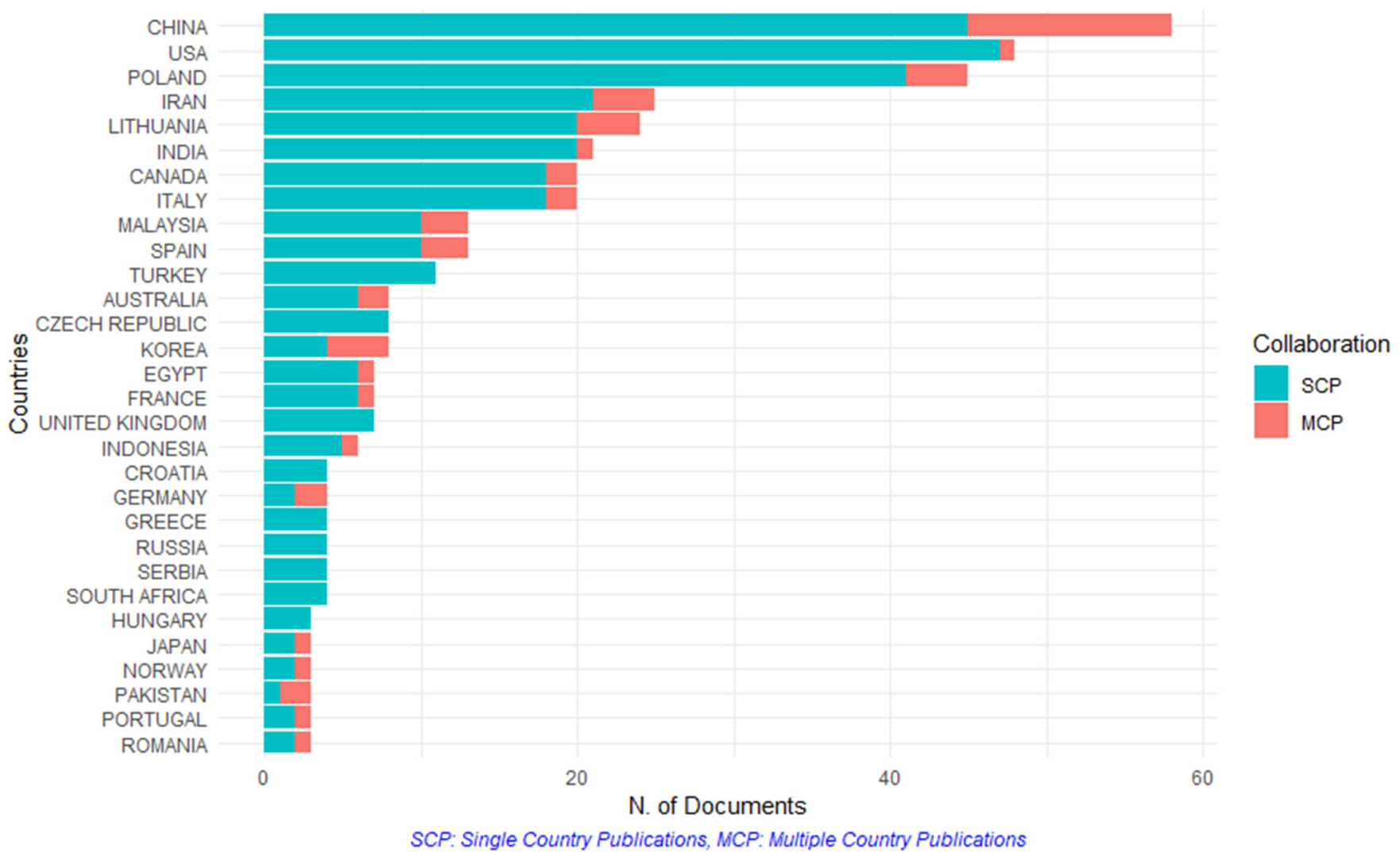

Figure 3. Most productive countries of corresponding authors (SCP (green) is the proportion of papers with all authors from the same country, while MCP (red) is the fraction of papers with authors from multiple countries).

The list of top 20 keywords, Table 2, contains only two typical multi-criteria methods (analytic hierarchy process (AHP) or its variations and TOPSIS). As might be expected from the search criteria, the keywords list is dominated by words associated with application areas (civil engineering; construction (including construction industry), water resources, sustainable development; environmental impact; climate change; and risk assessment). These are the areas where applications of MCDM are more likely to be reported. They have some key elements in common in that all three involve some element of design and of resource allocation. In addition, these areas have a high degree of complexity with large numbers of components or sub-processes to be managed and thus a very large number of possible configurations requiring some automated procedure to seek optimal solutions. Note that Engineering education is included in the list and this category includes a paper on MCDA education for sustainability [40].

Only four terms that could be considered as decision criteria are listed in the top 25, i.e., sustainable development (24 papers), environment (impact) (12 papers) risk (16 papers) and safety (11 papers). This is not surprising as sustainability, safety and concern for the environment are typically recognized as ethical responsibilities of engineers and incorporated into codes of ethics, e.g., for the ASCE (https:/ / www.asce.org/code-of-ethics/) (accessed on 24 March 2021) or for Engineers Ireland (https:/ / www.engineersireland.ie/Professionals/ News-Insights/Resource-centre/Regulations-and-governance/Code-of-ethics) (accessed on 24 March 2021). 
Table 2. Top 25 keywords in articles.

\begin{tabular}{ccc}
\hline Rank & Keywords & Number of Articles \\
\hline 1 & Decision making (or decision-making) & 62 \\
2 & Civil engineer & 46 \\
3 & Model & 42 \\
4 & Construction or (construction industry) & 36 \\
5 & Optimization & 35 \\
6 & System (or systems) & 32 \\
7 & Selection & 32 \\
8 & AHP (or Analytic Hierarchy Process) & 32 \\
9 & Management & 30 \\
10 & Water resources or (water management) & 30 \\
11 & Sustainable development & 24 \\
12 & Design & 22 \\
13 & Performance & 21 \\
14 & Framework & 16 \\
15 & Risk Assessment & 16 \\
16 & Engineering education & 14 \\
17 & Uncertainty analysis & 14 \\
18 & Climate change & 13 \\
19 & Criteria & 13 \\
20 & Environment & 12 \\
21 & TOPSIS & 12 \\
22 & GIS & 12 \\
23 & Project management & 11 \\
24 & Safety engineering & 11 \\
25 & & 11 \\
\hline
\end{tabular}

This indicates their importance in design and project decision making. However, surprisingly, other criteria for engineering design, such as resilience/robustness or best use of physical resources do not appear in this list. Human resources management is in the list, mainly as one of the factors to be managed, particularly in construction projects, or as a possible constraint in some circumstances. It is also a factor in choosing partners for a consortium, e.g., [41]. It is also surprising that cost does not appear in this top 25 list.

\subsection{Scope of Results}

Publications on decision support methods related to civil engineering are more closely associated with environmental, sustainability or risk conscious engineers, or projects. It could also be possible that engineers working in the environmental/sustainability areas are more likely to have the results of their analyses published. This may be a combination of (a) the engineer's decision to write a paper on their work and submit to a journal or conference or (b) more interest from journals or conferences in accepting such papers, or (c) choice of keywords. The latter may be an unintended effect of being too specific with all keywords. For example, there are some civil engineering related papers that this author knows that were not identified in the bibliometric search. As the journals concerned were indexed in the databases, the author's choice of keywords or article title did not include sufficiently broad terms relating to engineering to trigger the search criteria above. Examples of these are an early paper on the application of ELECTRE III to choosing stations for renovation in the Paris Metro system [42]. While in the civil engineering (transport) domain, it was published in an Operations Research journal and was not picked up in the literature search. Another example is a paper on using AHP for selecting wastewater treatment options in the developing world [43] which, although published in a mainstream Civil Engineering journal, was not picked up in the broad search. While it uses the AHP method it does not mention multi-criteria or any variation of that phrase, using "systems analysis technique" and "optimization" instead. While researchers looking for information on a specific method or type of application, will search using very specific keywords, review studies tend to use keywords with a broader scope and may miss some papers that do not have some such 
keywords. A mix of some very specific keywords together with some broad keywords indicating, e.g., the engineering discipline would have ensured these papers were selected.

Of the various methods listed in the background section above, only two MCDA methods appear in the keyword list and these are the Analytic Hierarchy Process (AHP) [6] and TOPIS [7], suggesting these are the most frequently used methods worldwide. This is further supported by the top ten list of papers cited by the documents in the database, Table 3. Three documents in the top ten are by Thomas Saaty, one describing the Analytic Hierarchy Process (AHP) method and the other two later papers describing its use in practice. The top ten also contains the paper by Hwang and Yoon describing the TOPSIS method. Additionally, two documents relating to outranking methods, i.e., the book by Belton and a review paper by Behzadian confirm that outranking methods [44] are widely known, if not as widely used as AHP.

Table 3. Publications most frequently cited by documents in database.

\begin{tabular}{cccc}
\hline Rank & Main Author & Citation Link & Method Used \\
\hline 1 & Saaty, T.L. & {$[6]$} & AHP \\
\hline 2 & Zadeh, L.A. & {$[45]$} & $\begin{array}{c}\text { Fuzzy sets approach-used in } \\
\text { some MCDA implementations }\end{array}$ \\
\hline 3 & Saaty, T.L. & {$[46]$} & AHP \\
\hline 4 & Hwang, C. & {$[7]$} & TOPSIS \\
\hline 5 & Saaty, T.L. & {$[47]$} & AHP \\
\hline 6 & Jato-Espino, D. & {$[48]$} & $\begin{array}{c}\text { Review of MCDA in } \\
\text { construction industry }\end{array}$ \\
\hline 8 & Belton, V. & {$[8]$} & $\begin{array}{c}\text { Book- mainly on ELECTRE (an } \\
\text { outranking method) }\end{array}$ \\
\hline 9 & Buckley, J.J. & {$[49]$} & $\begin{array}{c}\text { Application of Fuzzy analysis to } \\
\text { MCDA }\end{array}$ \\
\hline 10 & Chang, D.Y. & {$[50]$} & Fuzzy-AHP \\
\hline
\end{tabular}

Three other documents in Table 3 relate to the use of fuzzy sets in MCDA. These are the publication by Zadeh describing the concepts and methods of fuzzy sets and are accompanied by a further two papers, one by Buckley and the other by Chang describing methods that merge the concept of fuzzy sets with an MCDA method. These suggest that the basic MCDA techniques have reached a plateau level of maturity and that more recent publications relate to either (i) applications of the method(s), where a specific application or a review of applications in a specific topic (ii) combining the method(s) with some other concept, e.g., fuzzy sets.

Analysis of the list of journals most frequently associated with the papers in the broad-search database suggests that the first of these suggestions is dominant, Table 4 . The journals most frequently used are not narrowly focused, whether specifically on environmental, or sustainability topics but are more mainstream applied journals with a wide scope, except for one journal, Sustainability. The list includes several series of regular conferences that publish their proceedings, some quite high on this list, e.g., "World Multidisciplinary Civil Engineering-Architecture-Urban Planning Symposium" and the Annual Conference of the Canadian Society for Civil Engineering and the American Society for Engineering Education. This is consistent with the relatively high $(38 \%)$ number of conference papers returned in the bibliometric search. 
Table 4. Journals ranked by number of papers in broad search database (publisher in parentheses).

\begin{tabular}{cc}
\hline Title of Journal or Proceedings (Publisher) & Number of Documents in Database \\
\hline $\begin{array}{c}\text { Journal of Civil Engineering and Management (Publisher Vilnius } \\
\text { Gediminas Technical University) }\end{array}$ & 17 \\
\hline $\begin{array}{c}\text { KSCE Journal of Civil Engineering (Korean Society of Civil Engineers) } \\
\text { World Multidisciplinary Civil Engineering-Architecture-Urban Planning } \\
\text { Symposium-WMCAUS (Conference series-Prague) }\end{array}$ & 17 \\
\hline $\begin{array}{c}\text { Proceedings of the Annual Conference of the Canadian Society for Civil } \\
\text { Engineering-(Canadian Society for Civil Engineering) }\end{array}$ & 12 \\
\hline $\begin{array}{c}\text { Proceedings of the ASEE Annual Conference and Exposition (American } \\
\text { Society for Engineering Education) }\end{array}$ & 11 \\
\hline Civil Engineering and Environmental Systems (Taylor Francis) & 10 \\
\hline Archives of Civil Engineering (De Gruyter Open) [Poland] & 8 \\
\hline Canadian Journal of Civil Engineering (Canadian Science Publishing) & 8 \\
\hline Civil Engineering Journal-TEHRAN & 8 \\
\hline CIVIL-COMP Proceedings & 5 \\
\hline Journal of Applied Water Engineering and Research (Taylor and Francis) & 5 \\
\hline Structural Engineering and Mechanics (Techno Press) & 5 \\
\hline Sustainability (MDPI) & 5 \\
\hline
\end{tabular}

\section{Comparison with Focused Searches}

The analysis above indicates that broad search returns alone do not span the full range of publications on Civil Engineering Applications of MCDA. This is disappointing and may be very misleading for a researcher trying to gauge the extent of MCDA usage in Civil Engineering and/or to determine the most frequently used methods. This contrasts with searches undertaken on more specific aspects of Civil Engineering. For instance, Table 5 shows the number of articles returned from searches of Scopus using a combination of (\{multi criteria\} OR \{multi-criteria\} OR \{multi criterion\} OR \{multi-criterion\}) together with keywords or phrases for more specific topics in Civil Engineering listed in the first column. The results indicate a significant number of publications in each topic, except for Foundation design and Truss design. The third column of the table shows the number of publications each focused search had in common with the earlier main broad "Civil Engineering" search. It is striking that there are very few publications $(4.2 \%)$ in common between the broad and the focused searches. The highest percentage for an individual topic is $20 \%$ for "Bridge Design" but all the others have substantially lower percentages. Thus, even though the broader search with the Civil Engineering disciplines as keywords might have been expected to return many if not all the articles returned by the focused searches, a very substantial number of publications has been missed. To demonstrate the extent of what was missed, the individual papers for each of the focused searches were analyzed below, except for the two topics, "truss design" that had only 3 articles and "foundation design" which had none. 
Table 5. Effect of narrowing focus from discipline to topics.

\begin{tabular}{cccc}
\hline $\begin{array}{c}\text { Search Criteria: } \\
\text { All the Multi-Criteria Various } \\
\text { Listed in Section 4 Plus Topics } \\
\text { Listed below }\end{array}$ & $\begin{array}{c}\text { Number of } \\
\text { Publications Found }\end{array}$ & $\begin{array}{c}\text { Number of Publications in } \\
\text { Common with Broad Survey }\end{array}$ & $\begin{array}{c}\text { \% of Publications in } \\
\text { Common with Broad Survey }\end{array}$ \\
\hline Bridge Design & 15 & 3 & 20.0 \\
Earthquake Engineering & 26 & 3 & 11.5 \\
Cladding & 21 & 1 & 5.0 \\
Sewage Treatment & 38 & 0 & 2.6 \\
Foundation design & $0 *$ & 11 & 0 \\
Truss design & 3 & 11 & 2.1 \\
Water Supply & 535 & 2 & 3.1 \\
Building Energy & 86 & 1 & 7.1 \\
Route selection & 64 & 14 & \\
Transport mode & 14 & \\
\hline
\end{tabular}

${ }^{*}$ One publication returned but it was not relevant to search topic.

\section{Focus on Bridge Design}

The focused search for MCDA in Bridge Design returned 15 papers, of which, only 3 were in common with the general search. One of the papers was not relevant as it concerned bridges in electronic circuits. In two others, MCDA methods were not central to the paper but were only mentioned in the context of their potential for use in future research, in one case to develop a sustainability criterion [52], and in another in connection with an automated method for preliminary design of bridges, for instance choice of bridge type, form and materials [53].

One of the papers was a review of MCDA methods in life cycle sustainability in bridge design, [37], with a somewhat broader search criteria than used here. For instance, the broader term "Bridge" was used in the search string whereas here the more specific "Bridge Design" was used. In addition, the broader discipline "Engineering" was used instead of the various Civil Engineering categories used here. Their search produced an initial set of 31 articles for review. They found that, as here, AHP and SAW were the most common techniques overall but that, in recent years, PROMETHEE and TOPSIS were becoming more popular. MAUT was the least common method. Some specific examples of applications of MCDA to bridge design are given below and summarized in Table 6. In Brazil, a direct use of MCDA compared three bridge types (pre-cast concrete, mixed steel and concrete and timber) [54]. Two MCDA methods were used, AHP and VIKOR with five criteria, including two qualitative criteria, relating to aesthetics and the perception of safety. Both MCDA methods selected the mixed steel/concrete bridge as the best and interestingly, the wooden bridge scored lower on both qualitative criteria. A wider range (5) of candidate structural systems (Cast-in-place, Precast I-Girder, Incremental Launching, Balanced Cantilever, Advanced Shoring method) were considered for earthquake resistance bridges in Greece by [55], using the PROMETHEE method and seven criteria (Safety, Durability, Economy, Construction speed, Aesthetics, Serviceability, and Environmental harmony.) Safety was given the highest weight in the analysis, followed by Durability and Economy, while environmental harmonization was given the lowest weight. Uncertainty was taken into account in the analysis of [56] that used a fuzzy number formulation and optimization together with MCDA methods (AHP and VIKOR). However, only three criteria are used, embodied energy, overall safety, and corrosion initiation time. 
Table 6. Examples of MCDA applications in Bridge Design decisions.

\begin{tabular}{cccc}
\hline Topic & Method & No. Criteria & Notes \\
\hline$[54]$ & AHP, VIKOR & 5 & $\begin{array}{c}\text { Included qualitative criteria. Both } \\
\text { methods gave the same results }\end{array}$ \\
\hline$[55]$ & PROMETHEE & 7 & Includes earthquake resistance \\
\hline$[56]$ & AHP, VIKOR & 3 & $\begin{array}{c}\text { Links MCDA with an } \\
\text { optimization technique }\end{array}$ \\
\hline
\end{tabular}

\section{Focus on Earthquake Engineering}

The literature search focused on Civil Engineering aspects of MCDA in Earthquake engineering returned 26 articles, with only 3 in common with the broadly based search While a wide range of applications were covered in the articles, as described below, the most cited application areas were (a) the choice of methods for retrofitting buildings or bridges to improve their earthquake resilience, (b) choosing strategies for restoring transportation networks after earthquakes and (c) seismic risk mapping, mainly for structures in urban areas. A recent article reviewed and compared some MCDA methods applied to the seismic vulnerability of reinforced concrete buildings in Turkey [57]. By comparing the MCDM methods results with actual damaged experienced by the buildings, the study recommended TOPSIS.

For instance, MCDA methods were used to select a suitable type of passive damping system, using as criteria the structural response characteristics (acceleration, drift, displacement, velocity, and base shear) [58]. A multi-criteria method was used to prepare seismic risk maps for Ahmedabad, using AHP with a combination of physical criteria (overburden thickness, shear-wave velocity, liquefaction factor of safety and amplification factor, estimated peak ground acceleration) [59]. MCDA techniques were also used in a study of urban seismic risk in Romania [60] that included cultural identity as one of the criteria to be considered. In addressing a similar issue in Italy, [61], also used MCDA methods and included the strategic contribution of the buildings to the economy of the region as part of the selection strategy. In Turkey, a seismic risk map of Istanbul was produced by [62] using the AHP method with five criteria (topography, distance from source, soil type, liquification potential, fault mechanism). Weightings were derived from a survey of ten academic experts. Similarly, a regional risk zonation map for the Erbaa region of Turkey was produced by [63] using eight criteria (slope, aspect, lithology, depth to groundwater, distance from faults, soil shear wave velocity, amplification, and liquefaction potential). The problem of choosing glass façade systems for buildings in earthquake prone areas was addressed using three MCDA methods (AHP, TOPSIS and COPRAS) and ten criteria [64] and AHP and TOPSIS gave similar rankings. In India, AHP with fuzzy numbers was used to construct a performance assessment index for buildings damaged in the 2011 Sikkim earthquake, [65]. The use of the AHP method in construction risk management was reviewed by [54], but it did not have an earthquake focus. Managing the restoration of a complex transport network after an earthquake requires a complex prioritization of locations and the order in which they are repaired. For networks with a large number of damaged bridges, [66] applied a multi-dimensional optimization technique, focused on resilience and on minimizing the time required to achieve a specified level of functionality. The approach reduced the options to a "Pareto Front" of non-dominated solutions from which the manager could choose. More recently, approaches to developing appropriate criteria for this type of problem were described by [67] using Multi-Attribute Value Theory (MAVT). In a well-cited paper (20 citations in 2 years), a multi-criterion framework for assessing seismic risk to road networks was proposed $[68,69]$ with a focus on the GIS tools needed to describe the road networks and Monte Carlo simulation to investigate resilience criteria and proposed indicators for use in a decision support analysis, but did not propose any particular MCDA method. 
Approaches to retrofitting buildings to reduce their vulnerability to earthquakes were considered by $[70,71]$ who discussed the broad range of factors needed and suggested AHP as a suitable MCDA method. Subsequently, this method was used, together with TOPSIS, to rank retro-fit options to improve seismic resilience in existing buildings by [72] using seven criteria (Cost of retrofit, maintenance costs, duration of retrofit, functional compatibility (invasiveness of method), specialized labor requirements, interventions on foundations, potential loss (ratio of repair to reconstruction costs)). A general overview of issues relating to seismic resilience of buildings in Italy, [73], recommended that MCDA methods be used to select appropriate mitigation strategies. This advice was followed by [74] who used seven criteria (Installation cost, net tax refunds, risk improvement, cost of maintenance, duration of work, architectural impact and functional compatibility, and increase in force demand at the foundations). An interesting aspect of that work is a sensitivity analysis showing how decisions changed if the decision maker changed their attitude to balancing short-term vs. long-term benefits. Following on from this, [75] applied similar methods for choosing retrofitting strategies for schools in Lima. The study contains a useful list of criteria used in previous work and used a stakeholder collaborative workshop to narrow these to 6 for its own analysis (Installation cost, duration of work, seismic performance, feasibility of construction, ability to do incremental reinforcing, architectural and functional aspects). An important novelty is the integration with BIM tools for estimating the costs and durations of the options. Similarly, MCDA techniques were applied to the selection of bridge rehabilitation methods to improve seismic resilience [76], using the VIKOR method with 6 criteria (capacity, ductility, deformation, global stability, cost and duration of works). The VIKOR method was also used in selecting a passive vibration control system to use as a baseline to compare smart-passive and earthquake warning options for bridges in seismically risk areas [77]. Six technical criteria were used (peak overturning moment, peak midspan displacement, standard deviation of overturning moment, standard deviation of midspan displacement, number of earthquakes for which the smart-passive strategy gives lower overturning moment, and the number for which it gives lower midspan displacement). In [55], the PROMETHEE method was used, with weights determined by AHP, to choose a bridge construction method to reduce construction time using 7 criteria (Safety, Durability, Economy, Construction speed, Aesthetics, Serviceability, Environmental harmonization). The design and choice of material for elastomeric isolators to reduce vibration of buildings or bridges during seismic events involved both AHP and TOPSIS [78] using three criteria (vertical stiffness, horizontal stiffness and viscous damping). For foundations of buildings, in a study of the factors predicting liquifacation of soils, [79], AHP was used to consolidate the possible criteria to 5 main ones (Plasticity index, Effective vertical overburden pressure, ration of water content to liquid limit, mean particle size, and percentage clay content). Some key examples are summarized in Table 7.

Table 7. Examples of MCDA applications in Earthquake Engineering decisions.

\begin{tabular}{cccc}
\hline Citation & MCDA Method & Number of Criteria & Notes \\
\hline$[62]$ & AHP & - & Urban seismic risk map for Istanbul \\
\hline$[63]$ & AHP & 8 & Regional risk map Erbaa, Turkey \\
\hline$[64]$ & AHP, TOPSIS and COPRAS & - & AHP and TOPSIS gave similar rankings \\
\hline$[65]$ & AHP (fuzzy) & - & Building performance index \\
\hline$[72]$ & AHP and TOPSIS & 7 & $\begin{array}{c}\text { Retrofitting reinforced concrete buildings } \\
\text { for seismic resilience }\end{array}$ \\
\hline$[74]$ & TOPSIS & 7 & $\begin{array}{c}\text { Retrofitting buildings for seismic risk in } \\
\text { Italy. Includes tax incentive refunds } \\
\text { affecting costs }\end{array}$ \\
\hline$[55]$ & PROMETHEE & 7 & $\begin{array}{c}\text { Cost not included in the evaluation. } \\
\text { Weights from questionnaire } \\
\text { sent to } 7 \text { experts. }\end{array}$ \\
\hline
\end{tabular}


Table 7. Cont.

\begin{tabular}{cccc}
\hline Citation & MCDA Method & Number of Criteria & Notes \\
\hline$[79]$ & AHP & 5 & AHP used for initial selection of criteria. \\
\hline$[75]$ & AHP and TOPSIS & $\begin{array}{c}\text { Used BIM for estimating cost and } \\
\text { duration of works for each option. }\end{array}$ \\
\hline$[78]$ & AHP and TOPSIS & 3 & $\begin{array}{c}\text { Design and materials of } \\
\text { elastomeric isolators }\end{array}$ \\
\hline
\end{tabular}

\section{Focus on Cladding}

The focused search for MCDA in cladding returned 21 articles, with only one of these in common with the general civil engineering search. A considerable amount of useful information on the criteria used in selecting cladding systems to support a multicriteria approach to selections is given in [80]. For application examples, in a number of building contexts, [81-83] used simple additive weighting (SAW) following [84] despite being aware of the method's sensitivity to the addition or removal of alternatives that can change the ranking. They reviewed criteria used in the past and selected 4 for their study (efficiency, initial cost, maintenance costs (including inspections) and number of replacements over design life of building). In Ahmedabad, India, the selection of materials, including for cladding, for metro stations was addressed with a factor comparison approach using fuzzy numbers [85]. The focus was on minimizing embedded energy and the study reported a 75\% reduction in this. In Australia, AHP and a Delphi technique [86] were used to select materials for façade replacement [87]. The Delphi technique was used with a group of stakeholders to refine the criteria to be considered and to indicate stakeholders' opinions about their relative importance in a pair-wise comparison questionnaire. The final set of criteria headings used were (embodied energy and carbon, thermal effects, resource sustainability, life cycle costs, performance (incl. weight), social and environmental benefits) [87]. The appropriateness of plastics or composites in cladding was analyzed using a SAW technique with 7 main criteria (structural performance, fire safety class, thermal characteristics, ecological and health implications, durability, noise performance, and sustainability) [88]. When the materials for a building have been chosen, the issue of selecting a supplier arises and the Analytic Network Process (ANP) has been applied to this type of problem using ten criteria (cost, quality, delivery parameters, payment method, location, supplier profile, buyer-supplier relationship, ecological, capacity and materials characteristics) [89].

Two MCDA methods, AHP and MAUT, were applied to the design of curtain walls in office buildings by [90] who identified 32 criteria to be considered after a consultation process with stakeholders who consisted of both the designers and users of the office spaces. For building exteriors, a MCDA approach was suggested for taking account of the interactions of external ecological elements with building cladding and the implications for energy consumption and noise, particularly in relation to urban trees [91]. Table 8 summarizes the key papers. 
Table 8. Examples of MCDA applications in building cladding decisions.

\begin{tabular}{|c|c|c|c|}
\hline Citation & Method & No. Criteria & Notes \\
\hline [81-83] & SAW & 4 & $\begin{array}{l}\text { Noted SAW method is sensitive to number of } \\
\text { alternatives considered. }\end{array}$ \\
\hline [85] & Factor comparison & & \\
\hline [87] & AHP and Delphi & 6 (major groups) & $\begin{array}{l}\text { Interesting use of the Delphi technique to elicit information } \\
\text { from stakeholder workshops. }\end{array}$ \\
\hline [88] & SAW & 7 & Includes standards codes in consideration of criteria \\
\hline [89] & ANP & 10 & Stakeholder questionnaires used Likert scale for responses. \\
\hline [90] & AHP and MAUT & Up to 32 & $\begin{array}{l}\text { Uses questionnaire surveys of office space } \\
\text { designers and users. }\end{array}$ \\
\hline [91] & Not specified & n.a. & $\begin{array}{l}\text { Interactions of urban ecological elements with building } \\
\text { cladding- energy and noise. }\end{array}$ \\
\hline
\end{tabular}

\section{Focus on Sewage Treatment}

The use of MCDA in Sewage treatment mainly concerned three main sectors where decisions are required: (a) choice of treatment technology or its upgrade, (b) methods for disposal of the resulting sludge and (c) methods of disposing of treated wastewater liquids. A review of decision support systems in wastewater treatment plants documented the progression from life-cycle assessment, cost-benefit ratios, mathematical models through to the use of MCDA methods from about the year 2000 but did not focus on individual MCDM methods [92]. A method of validating similar DSS using case studies was reported by [93].

Looking at the various sectors individually, the choice of sewage treatment technology involves many decision criteria. The AHP method has been used for this in China with TOPSIS in a fuzzy number setting and ten key indicators (initial cost, recurring cost, land cost, reliability, durability, stability, resource recovery, simplicity, effect on ecosystems, and risk) [94]. The PROMETHEE method was applied to a related problem, improving the treatment processes as described in [95]. A similar problem was addressed by [96] using 10 criteria (capital cost, operational cost, water quality improvement, land required, ease of operation, maturity, reliability, public acceptability, employment, and government support). A bespoke environmental decision support system for selecting treatment technologies was described by [97] using criteria under three main headings, economic, environmental and technical. Options for remote villages converting from septic tank systems to a centralized treatment plant were analyzed using PROMETHEE [98] with 28 criteria divided between 4 groups (environmental, technical, financial and social) that were determined following stakeholder consultation. The same MCDA technique was used in Australia by [99] to choose upgrade options for sewage treatment plants in towns, this time with 17 criteria in five groups (financial, environmental, functional, health and social). In Surat City, [100] used a weighted average technique with 18 criteria to select sewage treatment options.

The question of sustainable disposal of sludge from sewage treatment plants is also important and a number of technologies for this have been assessed. For instance, various scenarios for using sludge for energy generation (incineration) has been examined using fuzzy MCDA techniques and twelve criteria (climate change, acidification, human toxicity, initial cost, recurring cost, life-cycle cost, social acceptance, health and safety implications, land requirement, reliability, efficiency of resource conversion, and operability) [101]. When sludge is dried, approximately $80 \%$ of the moisture can be removed and this can be helped with an additive and by controlling the temperature. MCDA was used to select the best combinations of these options using TOPSIS and MOORA with weights selected using CRITIC [17,102]. The selection of areas suitable for land-spreading of sludge was demonstrated in Spain by [103] who used a PROMETHEE type MCDA method, with 12 criteria, built into a GIS system. PROMETHEE was also used to identify soils suitable for locating on-site sewage treatment (septic tanks), using 8 criteria, mostly physical properties of the soils or porewater [104]. 
Sewage treatment produces a treated wastewater effluent requiring disposal. In some cases, this is via dilution in rivers. However, there is increasing pressure to find more sustainable disposal options that do not directly affect the quality of freshwaters. Such options include irrigation, re-use in some industries, spreading in green space such as forests or as land spreading in arid regions [105]. In some areas, the liquid outputs from sewage treatment can be used as irrigation water, but many factors control the suitability of areas for this, including the characteristics of the waste water, the soil and climate, crop type and aquifer vulnerability and these can be incorporated into a GIS-based decision support system to indicate suitable areas [106]. That study used 11 criteria spanning the environmental, technical, and financial domains. Deciding the contribution of treated wastewater to the mix of water from a variety of sources to meet water requirements in an arid area was investigated using AHP and 16 criteria [107] (for criteria see Table 1 in [107]).

Choosing locations for decentralized sewage treatment plants in a large city in Iraq was addressed by [108] who used AHP and five criteria (area, distance to nearest green area, slope, population density, and depth to the sewer connection). The depth to the sewer connection was important because of potential pumping costs. In contrast, the SAW method has been used with six criteria (energy required, sludge produced, grit production, biogas production, employment, and running costs) in deciding upgrade strategies of a centralized cluster of sewage treatment plants in Italy [109]. In Greece, [110] described a tools to assist with site selection for sewage treatment plants that can take account of 30 criteria, divided into five main categories (General including costs, land planning, geomorphological, hydrogeological and specialized criteria) and uses the PROMETHEE or ELECTRE methods.

In cities with combined sewer systems, inflows to sewage treatment works can be reduced using sustainable urban drainage systems (SUDS) to reduce rainwater inflows to the sewers. In Spain, [111] used SAW with a graphical display to select appropriate techniques using 4 criteria (total cost, GHG reduction from reduced treatment, aquifer recharge due to infiltration of rainwater and educational benefits). Some key papers are summarized in Table 9.

Table 9. Examples of MCDA applications in Sewage Treatment decisions.

\begin{tabular}{|c|c|c|c|}
\hline Citation & Method & No. Criteria & Notes \\
\hline [94] & Fuzzy AHP and TOPSIS & 10 & - \\
\hline [95] & PROMETHEE & 15 & Included odour as a criterion \\
\hline [96] & AHP based & 10 & Method adopted for use with groups \\
\hline [98] & PROMETHEE & 28 & $\begin{array}{l}\text { See Table } 1 \text { in [98] for list of criteria. Large number of } \\
\text { criteria demonstrate power of MCDA methods. }\end{array}$ \\
\hline [99] & PROMETHEE & 17 & $\begin{array}{c}\text { Developed a simple generic project schema—see } \\
\text { Figure } 1 \text { in [99] }\end{array}$ \\
\hline [100] & SAW & 18 & $\begin{array}{l}\text { Wide range of stakeholder groups determining } \\
\text { weights in a participatory approach }\end{array}$ \\
\hline [101] & Fuzzy methods based on TOPSIS & 12 & $\begin{array}{l}\text { Tested sensitivity to result to removal of a weight. As } \\
\text { might be expected, rank change can occur when some } \\
\text { criteria with the highest weights are removed. }\end{array}$ \\
\hline [102] & TOPSIS, MOORA and CRITIC & 11 & - \\
\hline [103] & Method linked to PROMETHEE & 12 & Used method with a GIS system \\
\hline [106] & AHP and GIS & 14 & Areas suitable for irrigation using treated wastewater \\
\hline [107] & AHP & 16 & - \\
\hline [108] & AHP & 5 & $\begin{array}{l}\text { Used in a GIS with a constrain to lie within a } 50 \mathrm{~m} \\
\text { buffer of an existing sewer. }\end{array}$ \\
\hline [109] & SAW & 5 & - \\
\hline [110] & PROMETHEE, ELECTRE & 30 & The tool is also suitable for landfill site selection. \\
\hline [111] & SAW & 4 & $\begin{array}{l}\text { Especially applicable in older cities with extensive } \\
\text { combined sewer systems. }\end{array}$ \\
\hline
\end{tabular}




\section{Focus on Route Selection}

The focused search for MCDA used in route selection returned 64 articles covering a wide variety of applications. Only 2 of the papers overlapped with the broad civil engineering search. Although it would be expected with route selection studies, very few articles integrated formal network analysis algorithms with the multi-criteria decision process. An exception is [112] who combined TOPSIS with Dijkstra's algorithm for finding the shortest path through a network. Other papers used artificial neural network (ANN) optimization methods (or a fuzzy number version, ANFIS [113]) for this, combined with AHP for determining the multi-criteria weights, see for instance [114]. It was interesting to note that in humanitarian relief and disaster management, the choice of access route(s) is an important factor in the planning of humanitarian logistics and was included in the articles found [115].

An example of selecting the best rapid transfer bus routes used 6 criteria (population density, existing routes, locations of bus stops, proximity to homes, proximity to nonresidential destinations and land use) and the AHP method [116]. In contrast, for selecting optimal cycling routes, [117] described a general procedure for determining Pareto optimal solution sets. In a later development, the best cycling routes in Imotske city (Croatia) were selected using fuzzy AHP and 5 criteria (length of route, type of road, slope, distance from emergency services, distance from refreshment facilities) [118]. Drivers' preferences were not explored in many articles, but [119] describes a method for finding and using these in route selection using a fuzzy neural network approach, ANFIS [113]. A method for selecting the route for a new monorail system for Ankara used ANP and TOPSIS and had fifteen criteria under four main headings (economic, social impact, performance, and environmental impact). To select routes for cruise ships in Venice, the SAW and MAVT methods were used with 30 criteria under three main headings (environmental, economic and social) [120]. Airlines use MCDM for selection of new routes. One example in Turkey used a fuzzy TOPSIS method with twelve criteria to select a new destination city for an expanding airline [121]. A GIS based method for oil and gas pipeline route selection was described by [122] and used Landsat satellite imagery in a GIS system and the AHP multi-criteria method. Below the sea surface, the selection of routes for subsea hydrocarbon pipes lines was addressed by [123] using fuzzy AHP and seven criteria (distance to environmentally sensitive features [there were $6 \mathrm{sub}$ categories of this criterion], distance to existing platforms, proximity to shipping activities, distance to exclusion zones, proximity to favorable seabed conditions, and distance to existing pipelines). Table 10 summarizes the more recent papers.

Table 10. Examples of applications of MCDA to route selection decisions.

\begin{tabular}{|c|c|c|c|}
\hline Citation & Method & No. Criteria & Notes \\
\hline [122] & AHP & - & $\begin{array}{l}\text { Oil and gas pipeline routes. Uses } \\
\text { Landsat imagery and GIS }\end{array}$ \\
\hline [116] & AHP & 6 & \\
\hline [118] & AHP, fuzzy & 5 & Bicycle routes (Imotske, Croatia) \\
\hline [120] & SAW with MAVT & 30 & $\begin{array}{l}\text { Cruise ships in Venice (Italy). } \\
\text { Did a sensitivity analysis of the } \\
\text { results to changes in weights }\end{array}$ \\
\hline [124] & ANP, TOPSIS & 15 & $\begin{array}{l}\text { Monorail system } \\
\text { (Ankara, Turkey) }\end{array}$ \\
\hline [123] & AHP, Fuzzy & 7 & Subsea hydrocarbon pipelines \\
\hline [121] & TOPSIS, fuzzy & 12 & $\begin{array}{l}\text { Selection of new destination city } \\
\text { in the USA for Turkish airlines. }\end{array}$ \\
\hline
\end{tabular}




\section{Focus on Transport Mode}

The focused search for MCDA and "Transport mode", returned 14 papers (with 1 paper overlapping with the broad civil engineering search) and most relevant to these keywords, for example [114] gave a simple conceptualization of the decision problem. However, one paper on MCDA and route selection was also returned because it was related to mode choice. That paper used AHP with nine criteria (Accident Prone Areas, Bus Lanes, Road Side Car Park, Bicycle Parks, Road Grade, Signalization, Traffic Capacity, Connected Bike Lane and Separated Bike Lane) and weights from a questionnaire survey of 460 cyclists in Isparta City in Turkey to select safe cycling routes that integrated with the public transport system [125].

The use of MCDA in group decision making in the transportation area has been reviewed by [126] with a special focus on selecting transport modes in supply chain management. The AHP (or ANP), ELECTRE and TOPSIS methods dominated their list. However, the transport mode topic is wider than supply chains. For instance, [127] analyzed the satisfaction of visitors to Valparaiso with their choice of transport mode using the fuzzy TOPSIS method with 16 criteria. Tourists who chose bus transport were most satisfied and those who chose rental cars were least satisfied. In Turkey, a variety of weighted sum approaches (SAW) were applied to the choice of mode for transport to airports, with a case study applied to Istanbul, in which underground metro was the preferred choice [128]. Twenty-four factors that influenced the transport choice of walking in a city were integrated into a GIS-based multi-criteria planning system and demonstrated for the European cities of Bologna and Porto [129]. Scenarios of pedestrian transport in Ramallah were prioritized according to 13 criteria using group decision making with stakeholders and the AHP method [130]. The AHP method was also used to prioritize the provision of advanced public transport mode choice in Korean cities [131]. Prioritization of light rail options in Belgium, [130], also used the AHP method with 13 criteria in four main groups (land use, social, environmental and economic). Interestingly, this study distinguished between criteria relating to the transport provider, local government stakeholders and regional government stakeholders including having separate weighting of the criteria for each group.

The availability and practicality of sustainable energy-based options may influence choice of transport modes. Thus, networks of electric vehicle charging stations may influence this choice and deciding on their locations is important. This issue was addressed in the city of Howra using fuzzy number formulations of AHP, TOPSIS and COPRAS using a total of thirteen criteria divided into four main groups (economic, environmental, traffic, and social) [132] and a sensitivity analysis in which the top ranking alternatives did not change, but the order of the lower ranking alternatives did change. The main papers are summarized in Table 11.

Table 11. Examples of applications of MCDA to Transport mode decisions.

\begin{tabular}{|c|c|c|c|}
\hline Citation & Method & No. Criteria & Notes \\
\hline [127] & TOPSIS (fuzzy) & 16 & Choice of transport mode by tourists (Valparaiso) \\
\hline [128] & SAW & 14 & Choice of transport mode to airport (Istanbul) \\
\hline [129] & Unspecified & 24 & $\begin{array}{l}\text { Factors influencing choice to walk in a city (Bologna } \\
\text { and Porto) }\end{array}$ \\
\hline [131] & AHP & 13 & $\begin{array}{l}\text { Reviewed } 47 \text { possible criteria from the literature and } \\
\text { reduced to the } 13 \text { used in their study. Interestingly, } \\
\text { they also distinguished between values for the } \\
\text { provider and values for the user of the service. }\end{array}$ \\
\hline [130] & AHP & 13 & $\begin{array}{l}\text { Distinguished between preferences of transport } \\
\text { provider and regional and local government } \\
\text { stakeholders. (various cities in Belgium) }\end{array}$ \\
\hline [132] & AHP, TOPSIS and COPRAS & 13 & $\begin{array}{l}\text { Choice of location for electric vehicle charging } \\
\text { stations in Howrah (India) with sensitivity analysis. }\end{array}$ \\
\hline
\end{tabular}




\section{Focus on Building Energy}

The focused search for papers on MCDA and Building Energy returned 86 papers and 11 of these were in common with the general civil engineering search. A wide variety of topics were covered, including how energy is provided to and how it is conserved in buildings. The paper by [133] gives a list of MCDA methods applied to the energy sector as well as applying versions of the additive weighting technique (SAW) to selecting HVAC systems for buildings, using 27 criteria organized into six groups (ergonomics, cost, technical properties, physical properties, flexibility, and reliability). The AHP method was used in an assessment of the energy performance of residential buildings in Saudi Arabia, using 3 criteria (Energy usage, Green House Gas emissions and cost) [134]. Energy simulation results can be combined with MCDA methods, for example for energy conscious choices of building facades using fuzzy AHP and TOPSIS with 9 criteria in four groups (thermophysical, economic, chemical, and environmental) [135] while AHP was used with 15 main criteria for a similar problem [136]. Note neither paper was found in the focused search for "cladding" described above, further emphasizing the importance of choice of keywords. Simple additive weighting (SAW) was used in the selection from retrofit options for buildings in Norway using seven criteria (energy reduction, costs, payback period, $\mathrm{CO}_{2}$ reduction, disturbance, indoor air quality, and aesthetics). That study took account of the different priorities of the occupants of the buildings, landlords and local government, with occupants' preferences different from the other two groups [137]. An interactive system for decision making for retrofitting, based on the "CommunityViz" ARCGIS extension (https:/ / communityviz.city-explained.com/index.html) (accessed on 24 March 2021) was described by [138]. It uses Simos' method [139] to determine stakeholders' weights using option cards sorted by the stakeholders.

The response of buildings to rising numbers of heat waves was assessed using AHP with seven criteria (temperature, sensible cooling, external surface temperature, radiant temperature at pedestrian level, external air temperature at pedestrian level, relative humidity at pedestrian level and wind speed at pedestrian level). Note that most of the criteria relate to conditions external to the building [140]. The methods can also be applied at a more detailed level, for instance in the selection of ventilation heat recovery devices for buildings, see [141], who used AHP with four main criteria (initial cost, running cost, performance, space requirement). The more recent papers are listed in Table 12.

Table 12. Examples of applications of MCDA to Building energy decisions.

\begin{tabular}{|c|c|c|c|}
\hline Citation & Method & No. Criteria & Notes \\
\hline [133] & SAW related & 27 & $\begin{array}{l}\text { HVAC selection for buildings. Additionally, } \\
\text { gives a list of energy related articles. }\end{array}$ \\
\hline$[134]$ & AHP & 3 & Residential buildings in Saudi Arabia. \\
\hline [135] & AHP, TOPSIS, fuzzy & 9 & $\begin{array}{l}\text { Façade design. Combined energy } \\
\text { simulation with MCDA method. }\end{array}$ \\
\hline [136] & AHP & 15 & Facade design. \\
\hline [138] & $\begin{array}{l}\text { Weights from Simos' } \\
\text { method [139] }\end{array}$ & 11 & $\begin{array}{l}\text { Uses CommunityViz spatial planning tool } \\
\text { to involve stakeholders in urban planning. }\end{array}$ \\
\hline [137] & SAW & 7 & $\begin{array}{l}\text { Took account of the different weightings } \\
\text { from different groups of stakeholders. }\end{array}$ \\
\hline [140] & $\mathrm{AHP}$ & 7 & Heat waves and buildings. \\
\hline [141] & AHP & 4 & Ventilation heat recovery in buildings. \\
\hline
\end{tabular}

\section{Focus on Water Supply}

The focused search of MCDA on water supply returned 535 articles of which only 11 overlapped with the general civil engineering search. Some literature reviews of aspects 
of this topic were found. An early review in 2006 of multi-criteria methods in water resources management found that both compensatory (e.g., AHP, ANP and MACBETH) and non-compensatory methods (e.g., ELECTRE and PROMETHEE) and fuzzy versions of these, were being applied at that time. A more up-to-date (2020) but very short review can be found in [142]. For the specific topic of water allocation, MCDA methods were reviewed by [143] who noted that optimization methods based on the genetic algorithm [144] were the most frequently reported.

Deciding between alternative future water supply alternatives in a city first requires forecasting future demand for water. This can be combined with MCDA methods to determine the preferred option. This was done for Istanbul (Turkey) with the PROMETHEE and TOPSIS methods applied to seven criteria (initial cost, operating cost, impact on the environment, impact on aquatic ecosystems, ease of operation, infrastructure requirements and social acceptability) [145]. ELECTRE III was used in a group decision-making context for selecting from water supply options [142,146] using ten criteria (climate, cost, reservoir capacity, environmental impacts, water quality, water consumption, groundwater resources, flood control, social effects, water transmission and diversion). Deciding on the best locations for harvesting rural rainstorm flows in Bengal (India) was done by linking a GIS system with the AHP method using three main criteria (land slope, soil type and stream drainage order) [147]. For rainwater harvesting in urban areas, [148] shows a visual method for selecting Pareto optimal options considering seven criteria related to both rainwater harvesting and flood reduction. Options for retrofitting water recovery plants (from wastewater flows) were selected using SAW and three criteria (water quality, robustness, economic) [149].

The optimal layout of district metering areas has been done by combining a k-means clustering algorithm, see [150], with MCDA methods such as AHP or TOPSIS using four criteria (cost, pressure, resilience and water quality) [151]. MCDA has also been used in selecting river water transfer options in Iran using AHP with 14 criteria grouped under 4 headings (environmental, economic, technical and socio-cultural) [152].

Selecting the best water distribution layout in Tamil Nadu (India) was addressed with a fuzzy MOORA-TOPSIS-VIKOR combination applied to five criteria (effectiveness, economic, time, social and environmental) [153]. Decisions relating to upgrading an existing network have been addressed using PROMETHEE and SAW with four criteria relating to (cost, pressure deficits, velocity limits and supply deficits) [154]. Some studies considered the usage and conservation of groundwater resources. For instance, areas suitable for Managed Aquifer Recharge (MAR) were identified near the South Africa/ Botswana border using SAW with nine criteria (land slope, land-use, soil, rainfall, proximity to water bodies, drainage density, depth to groundwater, lineament density, lithology), [155]. That study recognized that there were correlations between the criteria and took account of this in assigning weights. Various options for pumping and storing groundwater were investigated by [156] using 5 main groups of criteria (economic (divided into five sub categories), energy, environmental, water loss, and social) [156]. A combination of methods, AHP (for weights) and TOPSIS for the ranking, was applied to a case study in Spain, that showed how the optimal energy source changed depending on the depth and extent of the aquifer. In an EU project related to water supply in India, a software tool was developed to determine the best water treatment process. It was called the "WETSUIT" package [157] and used 30 objectives grouped under four headings (economic, socio-economic, technical and environmental) and the AHP method. Key papers on applications are listed in Table 13. 
Table 13. Examples of the application of MCDA in water supply decisions.

\begin{tabular}{|c|c|c|c|}
\hline Citation & Method & No. Criteria & Notes \\
\hline$[145]$ & PROMETHEE, TOPSIS & 7 & Istanbul (Turkey) water supply expansion \\
\hline [146] & ELECTRE III & 8 & Uses group decision making, applied in Iran. \\
\hline [147] & AHP & 3 & $\begin{array}{c}\text { Rainwater harvesting rural options } \\
\text { (Bengal, India) }\end{array}$ \\
\hline [148] & Visualisation & 7 & $\begin{array}{l}\text { Urban rainwater harvesting } \\
\text { and flood reduction }\end{array}$ \\
\hline [149] & SAW & 3 & Retrofitting water recovery plants \\
\hline [151] & $\begin{array}{l}\text { AHP, TOPSIS with } \\
\text { k-means clustering }\end{array}$ & 4 & Optimal design of district metering regions \\
\hline [152] & $\mathrm{AHP}$ & 14 & River water transfer selection in Iran \\
\hline [153] & MOORA, TOPSIS, VIKOR & 5 & Water distribution network design. \\
\hline [154] & PROMETHEE, SAW & 4 & Water distribution system upgrade. \\
\hline [155] & SAW & 9 & $\begin{array}{l}\text { Finding suitable areas for aquifer recharge. } \\
\text { This study explicitly took account of } \\
\text { interactions between criteria. }\end{array}$ \\
\hline [156] & TOPSIS/AHP & 9 & Groundwater pumping and storage solutions \\
\hline [157] & AHP & 30 & $\begin{array}{l}\text { WETSUIT tool for design of water treatment } \\
\text { works. Applied in India, the paper has a } \\
\text { detailed presentation and analysis of its results. } \\
\text { (for project information see } \\
\text { https:/ cordis.europa.eu/article/id/169860 } \\
\text {-water-treatment-solutions-for-india (accessed } \\
\text { on } 24 \text { March 2021)) }\end{array}$ \\
\hline
\end{tabular}

The eight special focus analyses above show that

(i) There is a very substantial difference in the articles returned from a bibliometric search using broad keywords compared to using focused keywords. This is despite the expectation that the broader keywords should cover the topics of the focused search. This is a concern for at least two reasons. (a) Many useful publications can be missed if the search terms are too broad, even when a large number of publications are returned by the broad search. Additionally, (b) even when the engineer doing the search realizes that focused keywords are more useful, there is an added responsibility to make sure the focused terms cover all of the domains required in the search.

(ii) The decision criteria keywords most frequently used in the broad search relate to sustainability, environment, risk, and safety, but cost does not feature in the list nor does physical resource usage.

(iii) The results of the individual focused searches had only marginal overlap with the earlier broad civil engineering searche. However, some returned a relatively large number of articles covering many aspects of the specific topic, especially the "route selection", "sewage treatment" and "water supply" searches.

(iv) While many MCDA methods are mentioned, AHP is by far the most used method, followed by TOPSIS and SAW. Many papers using AHP justify their choice because it is the most frequently used method. This is not a sufficiently rigorous position and more emphasis is needed on choosing the most appropriate MCDA method to suit the specific problem and the information available. The non-compensatory methods are not as frequently mentioned, but of these, PROMETHEE is the most prominent.

(v) In some cases, combinations of methods are used. For instance, AHP for determining weights has been used with TOPSIS for the decision methodology. PROMETHEE has 
also been used in conjunction with other methods. In one case, three methods were combined, AHP, TOPSIS and COPRAS.

(vi) In the applications papers reviewed above, the largest number of criteria used in an example was 32 and the minimum was 3 with a mode of 7 , so, in most cases, MCDA is being applied to decisions with considerable complexity.

(vii) Only a small number of papers mention the drawbacks of many of the methods, particularly the possibility of rank reversal [158] and its dependence on the number and type of alternatives considered in the analysis. This is disappointing because there are precautions that can be taken to mitigate this potential problem [159] and most of the articles analyzed here do not appear to address this issue.

(viii) While a reasonable number of papers integrated MCDA with GIS when the decisions had a spatial character, very few integrated with Building Information Systems (BIM). In the Civil Engineering context, more would be expected since BIM can be considered a major tool in the design and construction of structures [160].

(ix) Relevant papers known to this author did not trigger the bibliographic search criteria so were not selected. This emphasizes the important of using a mixture of specific and broad keywords to ensure papers are found and included in reviews.

(x) Papers are being published relating MCDA applied to Engineering education.

(xi) The main application areas have a high degree of complexity either in design or resource allocation configurations that benefit from an automated decision support capability.

(xii) Surprisingly, the name of any specific software package did not appear in the keywords of papers in the database. This may be because of a lack of awareness by Civil Engineers of the software support available, irrespective of which MCDA method they prefer. The following section lists some of the main packages available.

\section{Mainstream Software}

While it seems from the foregoing bibliometric analysis that there are gaps in the knowledge of Civil Engineers of the available MCDA software supporting decision making. The issue is not the availability of software to implement the various methods, nor of comparisons/assessments of these methods. There are numerous reviews of the current software tools, e.g., [161]. There are also many comparisons of the capabilities of some of the available these tools, e.g., https:/ / pubsonline.informs.org/magazine/orms-today / 20 20-decision-analysis-software-survey and https://www.informs.org/ORMS-Today/ORMS-Today-Software-Surveys/Decision-Analysis-Software-Survey/Page-1 (both accessed 24 March 2021).

As an attempt to remedy this, the available software has been surveyed and some of the more widely used (and readily available) packages identified and are shown in the following two Tables. The first of these, Table 14, lists a number of MCDA toolboxes, each containing a number of methods. Some of these are integrated into an easily used graphical user interface accessible through a web browser, such as ChemDecide and Decisionarium. Others provide modules that can be integrated by the user into a new, purpose built tool. While this offers considerably more flexibility, it requires a good knowledge of coding in either R (for the R MCDA package) or XML for Decision Deck. 
Table 14. MCDA Toolboxes of resources.

\begin{tabular}{|c|c|c|}
\hline Name & Description & Availability \\
\hline DEFINITE 3.1 & $\begin{array}{l}\text { A toolbox of evaluation methods including } \\
\text { Weighted summation, SMART, AHP, } \\
\text { ELECTRE 2, Regime Method, Graphical } \\
\text { Analysis and extensive sensitivity analysis. }\end{array}$ & $\begin{array}{l}\text { (https:/ / spinlab.vu.nl/support/tools/definite- } \\
\text { bosda/) (accessed on } 24 \text { March 2021) } \\
\text { [commercial but with reductions for academic } \\
\text { institutions] }\end{array}$ \\
\hline $\begin{array}{c}\text { Decision Deck } \\
\text { (linked to Diviz) }\end{array}$ & $\begin{array}{l}\text { A software workbench based on XML which } \\
\text { helps to design, execute, and share complex, } \\
\text { open source, MCDA/M algorithms } \\
\text { and experiments }\end{array}$ & $\begin{array}{l}\text { http://www.decision-deck.org/project/ } \\
\text { (accessed on } 24 \text { March 2021) } \\
\text { (looks like a good resource but needs } \\
\text { considerable skill to use) Additionally, links to } \\
\text { an R-based MCDA package (see below) } \\
\text { Cf. Mayer \& Bigaret (2012) }\end{array}$ \\
\hline $\mathrm{R}$ package for MCDA & $\begin{array}{l}\mathrm{R} \text { tools supporting the multi-criteria decision } \\
\text { aiding process: }\end{array}$ & $\begin{array}{l}\text { Free but requires knowledge of the R language. } \\
\text { https:/ / github.com/paterijk/MCDA (accessed } \\
\text { on } 24 \text { March 2021) }\end{array}$ \\
\hline ChemDecide & $\begin{array}{l}\text { A software package containing a decision } \\
\text { structuring tool and three analysis tools that } \\
\text { utilise AHP, ELECTRE III and MARE }\end{array}$ & $\begin{array}{l}\text { Developed by Dr. R.E. Hodgett, University of } \\
\text { Leeds and available through Britest Ltd. } \\
\text { Although originally developed with Chemical } \\
\text { storage and transport options selection in mind } \\
\text { is quite general. }\end{array}$ \\
\hline Decisionarium & $\begin{array}{l}\text { Web-based interface linking to tools for } \\
\text { decision support (for academic use) both } \\
\text { web-based (web-Hipre-java based AHP } \\
\text { tool) and some software for windows. Has } \\
\text { an online public participation facility. }\end{array}$ & $\begin{array}{l}\text { http:/ / decisionarium.tkk.fi/ (accessed on } 24 \\
\text { March 2021) } \\
\text { free for academic use. } \\
\text { Note: webpages lasted updated } 2013 . \\
\text { [162] }\end{array}$ \\
\hline IDSS software & $\begin{array}{l}\text { Collection of MCDM software of the } \\
\text { Laboratory of Intelligent Decision Support } \\
\text { Systems (University of Poznan, Poland). }\end{array}$ & $\begin{array}{l}\text { http: } \\
\text { / /idss.cs.put.poznan.pl/site/software.html } \\
\text { (accessed on } 24 \text { March 2021) }\end{array}$ \\
\hline
\end{tabular}

On the other hand, Table 15 lists some widely used packages, each implementing a single method or group of related methods. Unlike the bibliometric survey that indicated most publications focused on AHP and TOPSIS, the available tools offer a much broader range of methods, including the classic and axiomatically based Multi-Attribute Utility Theory [5] as well as AHP and TOPSIS, but extends to include the ELECTRE group of methods [9], PROMETHEE [51] and other approaches.

These tables show that there are many software options available to the engineer, some free and some commercial. The publications review suggests that users of MCDA in civil engineering and related areas do not make full use of this resource. This could be either because they are unaware of the available tools or they are not suitable. It cannot be because of cost since some tools are available free of charge. The lack of citations in the civil engineering literature to the wider group of methods suggests the former is the case. 
Table 15. MCDA Software packages—single method.

\begin{tabular}{|c|c|c|}
\hline Name & Description & Availability \\
\hline SuperDecisions & $\begin{array}{l}\text { Implementation of the Analytic Hierarchy Process and Analytic Network Process. } \\
\text { Supported by the Creative Decisions Foundation, started by Thomas Saaty. }\end{array}$ & $\begin{array}{l}\text { Free educational software and resources, see http:// www.superdecisions.com/ (accessed } \\
\text { on } 24 \text { March 2021) }\end{array}$ \\
\hline Expert Choice & Implements the Analytic Hierarchy Process and supports group decision making. & www.expertchoice.com (accessed on 24 March 2021) \\
\hline Visual PROMETHEE & Implements the PROMETHEE method & $\begin{array}{l}\text { www.promethee-gaia.net/ (accessed on } 24 \text { March 2021) } \\
\text { academic license available }\end{array}$ \\
\hline $\begin{array}{l}\text { Entscheidungsnavi } \\
\text { (decision navigation) }\end{array}$ & $\begin{array}{l}\text { A decision front end supporting the ideas, concepts, and methods of } \\
\text { value-focused thinking and a decision back end based on Multi-Attribute Utility } \\
\text { Theory (MAUT). }\end{array}$ & $\begin{array}{l}\text { A free decision support tool, available in German and English, see } \\
\text { https:/ / entscheidungsnavi.de/ (accessed on } 24 \text { March 2021) }\end{array}$ \\
\hline Mcda index & Web-based index tool & Ref. [163] (https:/ / www.mcdaindex.net/) (accessed on 24 March 2021) \\
\hline FITradeoff & $\begin{array}{l}\text { A Flexible and Interactive Tradeoff elicitation procedure for } \\
\text { multi-criteria additive models. }\end{array}$ & Commercial. (de Almeida, de Almeida et al. 2016, Frej, de Almeida et al. 2019). \\
\hline 1000 Minds & $\begin{array}{l}\text { Software for Multi-Criteria Decision-Making, prioritisation and } \\
\text { resource allocation. }\end{array}$ & $\begin{array}{l}\text { Commercial } \\
\text { Uses the PAPRIKA method (Hansen and Ombler 2008). }\end{array}$ \\
\hline DEXi & $\begin{array}{l}\text { A program for qualitative multi-attribute decision modelling, developed at the } \\
\text { Jožef Stefan Institute, Ljubljana, Slovenia. }\end{array}$ & $\begin{array}{l}\begin{array}{l}\text { Support through a single person's web-site. http://kt.ijs.si/MarkoBohanec/dexi.html } \\
\text { (accessed on } 24 \text { March 2021) }\end{array}\end{array}$ \\
\hline D-Sight & $\begin{array}{c}\text { A visual and interactive collaborative decision-making tool for multi-criteria } \\
\text { decision aid problems based on the PROMETHEE methods and Multi-Attribute } \\
\text { Utility Theory. }\end{array}$ & $\begin{array}{l}\text { http:// www.d-sight.com/ } \\
\text { (accessed on } 24 \text { March 2021) }\end{array}$ \\
\hline AHP-Online System & Implements the AHP method in a web browser using Java & Free, https://bpmsg.com/ahp/ahp.php (accessed on 24 March 2021) \\
\hline MACBETH & $\begin{array}{l}\text { Measuring Attractiveness by a Categorical Based Evaluation TecHnique in } \\
\text { MultiCriteria Decision Aid. }\end{array}$ & $\begin{array}{c}\text { (commercial with academic pricing) } \\
\text { http://m-macbeth.com/ (accessed on 24 March 2021) }\end{array}$ \\
\hline IRIS and VIP & $\begin{array}{l}\text { IRIS-Interactive Robustness analysis and parameters' Inference software for } \\
\text { multi-criteria Sorting problems using ELECTRE Tri and VIP-Variable } \\
\text { Interdependent Parameters Analysis software }\end{array}$ & https://www.uc.pt/en/feuc/ldias/software (accessed on 24 March 2021) \\
\hline Transparent Choice & AHP based decision software & $\begin{array}{l}\text { (https: / / www.transparentchoice.com/ahp-software) } \\
\text { (accessed on 24 March 2021) } \\
\text { [formerly called MakeItRational] }\end{array}$ \\
\hline Decision-Radar & A Python based TOPSIS and ELECTRE tool & $\begin{array}{c}\text { (Statistical Design Institute, 2016), see (https:// decision-radar.com/) and [164] (accessed } \\
\text { on } 24 \text { March 2021) }\end{array}$ \\
\hline ELECTRE I, II, III, IV and Tri & Software implementing the various ELECTRE group of methods. & $\begin{array}{c}\text { https:// sourceforge.net/projects/j-electre/files/ } \\
\text { https://github.com/Valdecy/J-Electre, also } \\
\text { https://www.lamsade.dauphine.fr/ mayag/links.html } \\
\text { ( all three accessed 24 March 2021) }\end{array}$ \\
\hline Best Worst Method & $\begin{array}{c}\text { A structured pairwise comparison system that involves comparisons with best } \\
\text { and worst options. }\end{array}$ & $\begin{array}{l}\text { https://bestworstmethod.com/ [165] } \\
\text { (accessed on } 24 \text { March 2021) }\end{array}$ \\
\hline
\end{tabular}




\section{Conclusions}

1. In a broad search, there was an overlap of only 13 documents between the results of the search of SCOPUS and of Web of Science and this indicates the advisability of accessing multiple databases when conducting a literature review.

2. The published literature on MCDA applications in civil engineering shows a wide geographical spread with Northern Hemisphere continents all represented. However, its coverage of the individual topic areas related to civil engineering is fragmented, focusing particularly on applications in the sustainability, environmental and risk areas and to some extent on project management decision making.

3. The published applications do not demonstrate a wide use of all available methodologies, as only two methods (AHP and TOPSIS) appeared in a keyword analysis. However, analysis of citations contained in the published papers did demonstrate some awareness of alternative methods.

4. There is a large difference between the results of searches using broad keywords and searches using focused keywords (Bridge Design, Earthquake Engineering, Cladding, Sewage Treatment, Foundation design, Truss design, Water Supply, Building Energy, Route selection and Transport mode). Engineers looking for the use of MCDA in specific focused topics should find relevant published work. However, searches trying to gauge the extent of use of MCDA in Civil Engineering may not uncover the full range of such applications or the methods used without a careful choice of search keywords and databases.

5. The previous point implies that communication of information, via publications, on MCDA between engineers could be improved by careful choice of keywords. This applies both to those making literature searches and to the authors of technical articles who seek the widest dissemination of their work and should choose appropriate keywords. A mixture of broad and focused keywords (where applicable) seems to be preferable.

6. There is a wide range of available software implementations of most methods, both free and licensed, however none feature highly in keyword lists or are mentioned in third-party published literature. This suggests a lack of awareness of the available software tools. Perhaps overview articles such as this one can help address this lacuna.

7. Thus, a wider dissemination of knowledge on both the methods themselves, but particularly on the availability and practical use of software implementations, is recommended for civil engineers. This could include both enhancement of the treatment of the topic in University engineering curricula as well as in Continuing Professional Development (CPD) programs for practicing engineers.

8. From the literature survey, it appears that civil engineers are not closely involved in developing new MCDA methodologies but tend to work in teams (most documents found in the search were multi-authored) and in the application of existing methods. The teamwork element is appropriate and is part of an engineers' formation. However, a more active role in developing decision support methods would be welcome.

Funding: This research received no external funding.

Institutional Review Board Statement: Not applicable.

Informed Consent Statement: Not applicable.

Data Availability Statement: Not applicable.

Conflicts of Interest: The author declares no conflict of interest.

\section{References}

1. Rogers, M.; Bruen, M. Non-monetary based decision-aid techniques in Environmental Impact Assessment-An overview. Proc. Instn. Civ. Engrs. Mun. Engr. 1995, 109, 98-103.

2. Stigler, G. The Development of Utility Theory. I. J. Political Econ. 1950, 58, 307-327. [CrossRef] 
3. Shogren, J.F.E. Encyclopedia of Energy, Natural Resource, and Environmental Economics; Shogren, J.F., Ed.; Elsevier: Amsterdam, The Netherlands, 2013.

4. Kaliszewski, I.; Podkopaev, D. Simple additive weighting-A metamodel for multiple criteria decision analysis methods. Expert Syst. Appl. 2016, 54, 155-161. [CrossRef]

5. Keeney, R.L.; Raiffa, H. Decisions with Multiple Objectives_Preferences and Value Tradeoffs; John Wiley: Hoboken, NJ, USA, 1976.

6. Saaty, T.L. The Analytic Hierarchy Process; McGraw-Hill: New York, NY, USA, 1980.

7. Hwang, C.L.; Yoon, K. Multi Atribute Decision Making: Methods and Applications: A State of the Art Survey; Springer: Berlin/Heidelberg, Germany, 1981.

8. Belton, V.; Stewart, T. Multiple Criteria Decision Analysis-An Integrated Approach; Springer: Berlin/Heidelberg, Germany, 2002.

9. Roy, B. The outranking approach and the foundations of electre methods. Theory Decis. 1991, 31, 49-73. [CrossRef]

10. Roy, B.; Hugonnard, J.C. Ranking of suburban line extension projects on the Paris metro system by a multicriteria method. Transp. Res. Part A Gen. 1982, 16, 301-312. [CrossRef]

11. Brans, J.P.; Vincke, P. Note-A Preference Ranking Organisation Method. Manag. Sci. 1985, 31, 647-656. [CrossRef]

12. Martel, J.-M.; Matarazzo, B. Other Outranking Approaches. In Multiple Criteria Decision Analysis: State of the Art Surveys; Figueira, J., Greco, S., Ehrogott, M., Eds.; Springer New York: New York, NY, USA, 2005; pp. 197-259. [CrossRef]

13. Greco, S.; Matarazzo, B.; Słowiński, R. Decision Rule Approach. In Multiple Criteria Decision Analysis: State of the Art Surveys; Greco, S., Ehrgott, M., Figueira, J.R., Eds.; Springer: New York, NY, USA, 2016.

14. Hamalainen, R.P.; Seppalainen, T.O. The analytic network process in energy-policy planning. Socio-Econ. Plan. Sci. 1986, 20, 399-405. [CrossRef]

15. Lichfield, N. Cost-benefit-analysis in city-planning. J. Am. Inst. Plan. 1960, 26, 273-279. [CrossRef]

16. Kaklauskas, A.; Zavadskas, E.K.; Raslanas, S.; Ginevicius, R.; Komka, A.; Malinauskas, P. Selection of low-e windows in retrofit of public buildings by applying multiple criteria method COPRAS: A Lithuanian case. Energy Build. 2006, 38, 454-462. [CrossRef]

17. Diakoulaki, D.; Mavrotas, G.; Papayannakis, L. Determining objective weights in multiple criteria problems: The critic method. Comput. Oper. Res. 1995, 22, 763-770. [CrossRef]

18. Costa, C.A.B.E.; Corte, J.-M.D.; Vansnick, J.-C. Macbeth. Int. J. Inf. Technol. Decis. Mak. 2012, 11, 359-387. [CrossRef]

19. Poyhonen, M.; Hamalainen, R.P. On the convergence of multiattribute weighting methods. Eur. J. Oper. Res. 2001, 129, 569-585. [CrossRef]

20. Brauers, W.K.M.; Zavadskas, E.K.; Peldschus, F.; Turskis, Z. Multi-objective decision-making for road design. Transport 2008, 23, 183-193. [CrossRef]

21. Simos, J. Evaluer L'impact sur L'environnement: Une Approche Originale par l'analyse Multicritere et la Negociation; Presses Polytechniques et Universitaires Romandes: Lausanne, Switzerland, 1990.

22. Zavadskas, E.K. and Antuchevičienè, J. Evaluation of buildings' redevelopment alternatives with an emphasis on the multipartite sustainability. Int. J. Strateg. Prop. Manag. 2004, 8, 121-128. [CrossRef]

23. Araña, J.E.; León, C.J. Understanding the use of non-compensatory decision rules in discrete choice experiments: The role of emotions. Ecol. Econ. 2009, 68, 2316-2326. [CrossRef]

24. Abbas, A.E. Constructing Multiattribute Utility Functions for Decision Analysis. In Risk and Optimization in an Uncertain World; Informs: Catonsville, MD, USA, 2010; pp. 62-98. [CrossRef]

25. Munda, G.; Nardo, M. Noncompensatory/nonlinear composite indicators for ranking countries: A defensible setting. Appl. Econ. 2009, 41, 1513-1523. [CrossRef]

26. Sałabun, W.; Watróbski, J.; Shekhovtsov, A. Are MCDA methods benchmarkable? A comparative study of TOPSIS, VIKOR, COPRAS, and PROMETHEE II methods. Symmetry 2020, 12, 1549. [CrossRef]

27. Cinelli, M.; Kadziński, M.; Gonzalez, M.; Słowiński, R. How to support the application of multiple criteria decision analysis? Let us start with a comprehensive taxonomy. Omega 2020, 96, 102261. [CrossRef]

28. Zavadskas, E.K.; Antuchevičienė, J.; Kapliński, O. Multi-criteria decision making in civil engineering: Part I-A state-of-the-art survey. Eng. Struct. Technol. 2016, 7, 103-113. [CrossRef]

29. Ogrodnik, K. Multi-Criteria Analysis of Design Solutions in Architecture and Engineering: Review of Applications and a Case Study. Buildings 2019, 9, 244. [CrossRef]

30. Ghaleb, A.M.; Kaid, H.; Alsamhan, A.; Mian, S.H.; Hidri, L. Assessment and Comparison of Various MCDM Approaches in the Selection of Manufacturing Process. Adv. Mater. Sci. Eng. 2020, 2020. [CrossRef]

31. Maciol, A.; Rebiasz, B. Multicriteria decision analysis (MCDA) methods in life cycle assessment (LCA). A comparison of private passenger vehicles. Oper. Res. Decis. 2018, 28, 5-26. [CrossRef]

32. Srisawat, C.; Payakpate, J. COMPARISON of mcdm methods for intercrop selection in rubber plantations. J. Inf. Commun. Technol. Malays. 2016, 15, 165-182. [CrossRef]

33. Kralik, L.; Senkerik, R.; Jasek, R. Comparison of MCDM methods with Users' Evaluation. In Proceedings of the 2016 11 th Iberian Conference on Information Systems and Technologies, Gran Canaria, Spain, 15-18 June 2016.

34. Kittur, J.; Vijaykumar, S.; Bellubbi, V.P.; Vishal, P.; Shankara, M.G. Comparison of Different MCDM Techniques Used to Evaluate Optimal Generation; Institute of Electrical and Electronics Engineers (IEEE): New York, NY, USA, 2015; pp. 172-177.

35. Sojda, R.S. Empirical evaluation of decision support systems: Needs, definitions, potential methods, and an example pertaining to waterfowl management. Environ. Model. Softw. 2007, 22, 269-277. [CrossRef] 
36. Myšiak, J. Consistency of the Results of Different MCA Methods: A Critical Review. Environ. Plan. C Gov. Policy 2006, 24, 257-277. [CrossRef]

37. Navarro, I.J.; Penadés-Plà, V.; Martínez-Muñoz, D.; Rempling, R.; Yepes, V. Life cycle sustainability assessment for multi-criteria decision making in bridge design: A review. J. Civ. Eng. Manag. 2020, 26, 690-704. [CrossRef]

38. Aria, M.; Cuccurullo, C. bibliometrix: An R-tool for comprehensive science mapping analysis. J. Informetr. 2017, 11, 959-975. [CrossRef]

39. Chen, J.; Konstan, J.A. Conference paper selectivity and impact. Commun. Acm 2010, 53, 79-83. [CrossRef]

40. Navarro Martinez, I.; Yepes Piqueras, V.; Marti Albinana, J.B. Multi-criteria decision making in engineering eduation for sustainability. In Proceedings of the ICERI2018 Conference, Seville, Spain, 12-14 November 2018.

41. Dadpour, M.; Shakeri, E. A Hybrid Model Based on Fuzzy Approach Type II to Select Private Sector in Partnership Projects. Iran. J. Sci. Technol. Trans. Civ. Eng. 2017, 41, 175-186. [CrossRef]

42. Roy, B.; Présent, M.; Silhol, D. A programming method for determining which Paris metro stations should be renovated. Eur. J. Oper. Res. 1986, 24, 318-334. [CrossRef]

43. Ellis, K.V.; Tang, S.L. Wastewater Treatment Optimization Model for Developing World. I: Model Development. J. Environ. Eng. 1991, 117, 501-518. [CrossRef]

44. Bouyssou, D. Outranking methods. In Encyclopedia of Optimization; Floudas, C.A., Pardalos, P.M., Eds.; Springer: Boston, MA, USA, 2009; pp. 2887-2893. [CrossRef]

45. Zadeh, L.A. Fuzzy Sets. Inf. Control 1965, 8, 338-353. [CrossRef]

46. Saaty, T.L. Decision Making with the Analytic Hierarchy Process. Intern. J. Serv. Sci. 2008, 1, 83-98. [CrossRef]

47. Saaty, T.L. How to make a decision: The analytic hierarchy process. Eur. J. Oper. Res. 1990, 48, 9-26. [CrossRef]

48. Jato-Espino, D.; Castillo-Lopez, E.; Rodriguez-Hernandez, J.; Canteras-Jordana, J.C. A review of application of multi-criteria decision making methods in construction. Autom. Constr. 2014, 45, 151-162. [CrossRef]

49. Buckley, J.J. Fuzzy hierarchical analysis. Fuzzy Sets Syst. 1985, 17, 233-247. [CrossRef]

50. Chang, D.-Y. Applications of the extent analysis method on fuzzy AHP. Eur. J. Oper. Res. 1996, 95, 649-655. [CrossRef]

51. Behzadian, M.; Kazemzadeh, R.B.; Albadvi, A.; Aghdasi, M. PROMETHEE: A comprehensive literature review on methodologies and applications. Eur. J. Oper. Res. 2010, 200, 198-215. [CrossRef]

52. Ek, K.; Mathern, A.; Rempling, R.; Brinkhoff, P.; Karlsson, M.; Norin, M. Life Cycle Sustainability Performance Assessment Method for Comparison of Civil Engineering Works Design Concepts: Case Study of a Bridge. Int. J. Environ. Res. Public Health 2020, 17, 7909. [CrossRef]

53. Rempling, R.; Mathern, A.; Tarazona Ramos, D.; Luis Fernández, S. Automatic structural design by a set-based parametric design method. Autom. Constr. 2019, 108, 102936. [CrossRef]

54. Kripka, M.; Yepes, V.; Milani, C.J. Selection of Sustainable Short-Span Bridge Design in Brazil. Sustainability 2019, 11, 1307. [CrossRef]

55. Markogiannaki, O.G.; Tegos, N.I. Towards accelerated construction and cost reduction of monolithical bridges facing earthquake hazard. In COMPDYN Proceedings-Crete; Institute of Structural Analysis and Antiseismic Research, NTU Athens: Athens, Greece, 2019; pp. 3747-3760.

56. García-Segura, T.; Penadés-Plà, V.; Yepes, V. Sustainable bridge design by metamodel-assisted multi-objective optimization and decision-making under uncertainty. J. Clean. Prod. 2018, 202, 904-915. [CrossRef]

57. Harirchian, E.; Jadhav, K.; Mohammad, K.; Aghakouchaki Hosseini, S.E.; Lahmer, T. A Comparative Study of MCDM Methods Integrated with Rapid Visual Seismic Vulnerability Assessment of Existing RC Structures. Appl. Sci. 2020, 10, 6411. [CrossRef]

58. Barkhordari, M.S.; Tehranizadeh, M. Ranking passive seismic control systems by their effectiveness in reducing responses of high-Rise buildings with concrete shear walls using multiple-Criteria decision making. Int. J. Eng. Trans. B Appl. 2020, 33, 1479-1490. [CrossRef]

59. Dwivedi, V.K.; Dubey, R.K.; Pancholi, V.; Rout, M.M.; Singh, P.; Sairam, B.; Chopra, S.; Rastogi, B.K. Multi criteria study for seismic hazard assessment of UNESCO world heritage Ahmedabad City, Gujarat, Western India. Bull. Eng. Geol. Environ. 2020, 79, 1721-1733. [CrossRef]

60. Georgescu, E.; Gociman, C.; Craifaleanu, I.; Florescu, T.; Georgescu, M.; Moscu, C. Architectural vs. structural constraints in urban multi-hazard safety assessment. In Proceedings of the 3rd International Conference on Structures and Architecture, ICSA 2016, Atlanta, GA, USA, 12-15 June 2016; pp. 1302-1309.

61. Vona, M.; Murgante, B. Seismic retrofitting of strategic buildings based on multi-criteria decision-making analysis. In Proceedings of the 4th International Symposium on Life-Cycle Civil Engineering, IALCCE 2014, Tokyo, Japan, 16-19 November 2014; pp. $1846-1851$.

62. Karaman, H.; Erden, T. Net earthquake hazard and elements at risk (NEaR) map creation for city of Istanbul via spatial multi-criteria decision analysis. Nat. Hazards 2014, 73, 685-709. [CrossRef]

63. Akin, M.K.; Topal, T.; Kramer, S.L. Seismic microzonation of Erbaa, Tokat Province, Turkey, based on analytical hierarchical process. Environ. Eng. Geosci. 2012, 18, 191-207. [CrossRef]

64. Ilter, E.; Celik, O.C.; Unlu, A. Multi-criteria performance evaluation of a glass panel system using full-scale experimental data. Archit. Sci. Rev. 2020. [CrossRef] 
65. Roshan, P.; Pal, S.; Kumar, R. Performance Assessment Indexing of Buildings Through Fuzzy AHP Methodology. Lect. Notes Civil Eng. 2020, 58, 503-519.

66. Bocchini, P.; Frangopol, D.M. Restoration of bridge networks after an earthquake: Multicriteria intervention optimization. Earthq. Spectra 2012, 28, 427-455. [CrossRef]

67. Zamanifar, M.; Hartmann, T. Decision attributes for disaster recovery planning of transportation networks; A case study. Transp. Res. Part D Transp. Environ. 2021, 93, 102771. [CrossRef]

68. Kilanitis, I.; Sextos, A. Integrated seismic risk and resilience assessment of roadway networks in earthquake prone areas. Bull. Earthq. Eng. 2019, 17, 181-210. [CrossRef]

69. Sextos, A.G.; Kilanitis, I. Methodology, software and policy for optimum seismic resilience of highway networks. In Proceedings of the 11th National Conference on Earthquake Engineering 2018, Los Angeles, CA, USA, 25-29 June 2018; pp. $2939-2949$.

70. Bostenaru Dan, M.D. Multi-criteria decision model for retrofitting existing buildings. Nat. Hazards Earth Syst. Sci. 2004, 4, 485-499. [CrossRef]

71. Bostenaru Dan, M.D. Review of retrofit strategies decision system in historic perspective. Nat. Hazards Earth Syst. Sci. 2004, 4, 449-462. [CrossRef]

72. Gentile, R.; Galasso, C. Optimal retrofit selection for seismically-deficient RC buildings based on simplified performance assessment. In COMPDYN Proceedings Crete; Institute of Structural Analysis and Antiseismic Research, NTU Athens: Athens, Greece, 2019; pp. 1146-1160.

73. Vona, M.; Harabaglia, P.; Murgante, B. Thinking about resilient cities: Studying Italian earthquakes. Proc. Inst. Civ. Eng. Urban Des. Plan. 2016, 169, 185-199. [CrossRef]

74. Caterino, N.; Cosenza, E. A multi-criteria approach for selecting the seismic retrofit intervention for an existing structure accounting for expected losses and tax incentives in Italy. Eng. Struct. 2018, 174, 840-850. [CrossRef]

75. Santa-Cruz, S.; Brioso, X.; Córdova-Arias, C. Selection of seismic retrofitting techniques through a multi-criteria methodology and BIM tools to improve transparency. In Proceedings of the 11th National Conference on Earthquake Engineering 2018, Los Angeles, CA, USA, 25-29 June 2018; pp. 2517-2526.

76. Ćosić, M.; Folić, R.; Folić, B. Multidisciplinary Approach to the Assessment of Seismic Performances and Rehabilitation of Bridges: Nonlinear Analyses, Probability Theory and Optimization Theory. Procedia Eng. 2016, 156, 83-90. [CrossRef]

77. Maddaloni, G.; Caterino, N.; Nestovito, G.; Occhiuzzi, A. Exploring New Boundaries to Mitigate Structural Vibrations of Bridges in Seismic Regions: A Smart Passive Strategy. Shock Vib. 2016, 2016, 4528168. [CrossRef]

78. Hedayati Dezfuli, F.; Alam, M.S. Multi-criteria optimization and seismic performance assessment of carbon FRP-based elastomeric isolator. Eng. Struct. 2013, 49, 525-540. [CrossRef]

79. Jain, R.K.; Purandare, A.S. Validation of the proposed liquefaction criterion of sand with fines by static tri-axial shear testing. Int. J. Civ. Eng. Technol. 2018, 9, 31-40.

80. Takano, A.; Hughes, M.; Winter, S. A multidisciplinary approach to sustainable building material selection: A case study in a Finnish context. Build. Environ. 2014, 82, 526-535. [CrossRef]

81. Ferreira, C.; Dias, I.S.; Silva, A.; de Brito, J.; Flores-Colen, I. Criteria for selection of cladding systems based on their maintainability. J. Build. Eng. 2021, 39, 102260. [CrossRef]

82. Ferreira, C.; Silva, A.; de Brito, J.; Dias, I.S.; Flores-Colen, I. Definition of a condition-based model for natural stone claddings. J. Build. Eng. 2021, 33, 101643. [CrossRef]

83. Ferreira, C.; Silva, A.; de Brito, J.; Dias, I.S.; Flores-Colen, I. Maintenance modelling of ceramic claddings in pitched roofs based on the evaluation of their in situ degradation condition. Infrastructures 2020, 5, 77. [CrossRef]

84. Dodgson, J.; Spackman, M.; Pearman, A.; Phillips, L. Multi-Criteria Analysis: A Manual. 2009. Available online: https://assets.publishing.service.gov.uk/government/uploads/system/uploads/attachment_data/file/191506/Mult-crisis_ analysis_a_manual.pdf (accessed on 24 March 2021).

85. Bapat, H.; Sarkar, D.; Gujar, R. Application of integrated fuzzy FCM-BIM-IoT for sustainable material selection and energy management of metro rail station box project in western India. Innov. Infrastruct. Solut. 2021, 6, 73. [CrossRef]

86. Helmer-Hirschberg, O. Analysis of the Future: The Delphi Method; RAND Corporation: Santa Monica, CA, USA, 1967.

87. Moussavi Nadoushani, Z.S.; Akbarnezhad, A.; Ferre Jornet, J.; Xiao, J. Multi-criteria selection of façade systems based on sustainability criteria. Build. Environ. 2017, 121, 67-78. [CrossRef]

88. Friedrich, D.; Luible, A. Assessment of standard compliance of Central European plastics-based wall cladding using multi-criteria decision making (MCDM). Case Stud. Struct. Eng. 2016, 5, 27-37. [CrossRef]

89. Cengiz, A.E.; Aytekin, O.; Ozdemir, I.; Kusan, H.; Cabuk, A. A Multi-criteria Decision Model for Construction Material Supplier Selection. In Procedia Engineering; Elsevier Ltd.: Amsterdam, The Netherlands, 2017; pp. 294-301. [CrossRef]

90. Hamida, H.; Alshibani, A. A multi-criteria decision-making model for selecting curtain wall systems in office buildings. J. Eng. Des. Technol. 2020. [CrossRef]

91. Guarini, M.R.; Morano, P.; Sica, F. Integrated ecosystem design: An evaluation model to support the choice of eco-compatible technological solutions for residential building. Energies 2019, 12, 2659. [CrossRef]

92. Mannina, G.; Rebouças, T.F.; Cosenza, A.; Sànchez-Marrè, M.; Gibert, K. Decision support systems (DSS) for wastewater treatment plants-A review of the state of the art. Bioresour. Technol. 2019, 290. [CrossRef] [PubMed] 
93. Castillo, A.; Porro, J.; Garrido-Baserba, M.; Rosso, D.; Renzi, D.; Fatone, F.; Gómez, V.; Comas, J.; Poch, M. Validation of a decision support tool for wastewater treatment selection. J. Environ. Manag. 2016, 184, 409-418. [CrossRef] [PubMed]

94. Liu, B.; Tang, J.; Li, Z.; Yan, Y.; Chen, J. Optimal Selection of Sewage Treatment Technologies in Town Areas: A Coupled Multi-Criteria Decision-Making Model. Environ. Manag. 2020, 66, 709-721. [CrossRef]

95. Munasinghe-Arachchige, S.P.; Abeysiriwardana-Arachchige, I.S.A.; Delanka-Pedige, H.M.K.; Nirmalakhandan, N. Sewage treatment process refinement and intensification using multi-criteria decision making approach: A case study. J. Water Process Eng. 2020, 37. [CrossRef]

96. Ren, J.; Liang, H. Multi-criteria group decision-making based sustainability measurement of wastewater treatment processes. Environ. Impact Assess. Rev. 2017, 65, 91-99. [CrossRef]

97. Garrido-Baserba, M.; Reif, R.; Molinos-Senante, M.; Larrea, L.; Castillo, A.; Verdaguer, M.; Poch, M. Application of a multi-criteria decision model to select of design choices for WWTPs. Clean Technol. Environ. Policy 2016, 18, 1097-1109. [CrossRef]

98. Tjandraatmadja, G.; Sharma, A.K.; Grant, T.; Pamminger, F. A Decision Support Methodology for Integrated Urban Water Management in Remote Settlements. Water Resour. Manag. 2013, 27, 433-449. [CrossRef]

99. Diaper, C.; Sharma, A. Innovative sewerage solutions for small rural towns. In Water Science and Technology; International Water Association: London, UK, 2007; Volume 56, pp. 97-103.

100. Vashi, A.N.; Shah, N.C. Impacts of a participatory approach to assess sustainable sewage treatment technologies for urban fringe of Surat city in India. In Water Science and Technology; International Water Association: London, UK, 2008; Volume 57, pp. $1957-1962$.

101. Tang, C.; Xu, D.; Chen, N. Sustainability prioritization of sewage sludge to energy scenarios with hybrid-data consideration: A fuzzy decision-making framework based on full consistency method and fusion ranking model. Environ. Sci. Pollut. Res. 2021, 28, 5548-5565. [CrossRef] [PubMed]

102. Gomes, L.A.; Santos, A.F.; Pinheiro, C.T.; Góis, J.C.; Quina, M.J. Screening of waste materials as adjuvants for drying sewage sludge based on environmental, technical and economic criteria. J. Clean. Prod. 2020, 259. [CrossRef]

103. Passuello, A.; Cadiach, O.; Perez, Y.; Schuhmacher, M. A spatial multicriteria decision making tool to define the best agricultural areas for sewage sludge amendment. Environ. Int. 2012, 38, 1-9. [CrossRef] [PubMed]

104. Carroll, S.; Goonetilleke, A.; Dawes, L. Framework for soil suitability evaluation for sewage effluent renovation. Environ. Geol. 2004, 46, 195-208. [CrossRef]

105. Vaseghi, E.; Zare Mehrjerdi, M.R.; Boshrabadi, H.M.; Nikouei, A. Prioritizing potential use of urban treated wastewater using expert-oriented and multi-criteria decision-making approaches: A case study in Iran. Water Sci. Technol. 2020, 82, 81-96. [CrossRef] [PubMed]

106. Zolfaghary, P.; Zakerinia, M.; Kazemi, H. A model for the use of urban treated wastewater in agriculture using multiple criteria decision making (MCDM) and geographic information system (GIS). Agric. Water Manag. 2021, 243. [CrossRef]

107. Aldababseh, A.; Temimi, M.; Maghelal, P.; Branch, O.; Wulfmeyer, V. Multi-criteria evaluation of irrigated agriculture suitability to achieve food security in an arid environment. Sustainability 2018, 10, 803. [CrossRef]

108. Hama, A.R.; Al-Suhili, R.H.; Ghafour, Z.J. A multi-criteria GIS model for suitability analysis of locations of decentralized wastewater treatment units: Case study in Sulaimania, Iraq. Heliyon 2019, 5. [CrossRef] [PubMed]

109. De Gisi, S.; Pica, R.; Casella, P.; Notarnicola, M. Dealing with a cluster of large centralized municipal wastewater treatment plants: A case study. Process Saf. Environ. Prot. 2018, 118, 268-278. [CrossRef]

110. Vasiloglou, V.; Lokkas, F.; Gravanis, G. New tool for wastewater treatment units location. Desalination 2009, 248, 1039-1048. [CrossRef]

111. Rodríguez-Sinobas, L.; Zubelzu, S.; Perales-Momparler, S.; Canogar, S. Techniques and criteria for sustainable urban stormwater management. The case study of Valdebebas (Madrid, Spain). J. Clean. Prod. 2018, 172, 402-416. [CrossRef]

112. Roghanian, E.; Kebria, Z.S. The combination of TOPSIS method and Dijkstra's algorithm in multi-attribute routing. Sci. Iran. 2017, 24, 2540-2549. [CrossRef]

113. Jang, J.R. ANFIS: Adaptive-network-based fuzzy inference system. Ieee Trans. Syst. ManCybern. 1993, 23, 665-685. [CrossRef]

114. Qu, L.; Chen, Y. A hybrid MCDM method for route selection of multimodal transportation network. In Lecture Notes in Computer Science (Including Subseries Lecture Notes in Artificial Intelligence and Lecture Notes in Bioinformatics); Springer: Berlin/Heidelberg, Germany, 2008; Volume 5263, pp. 374-383.

115. Nappi, M.M.L.; Nappi, V.; Souza, J.C. Multi-criteria decision model for the selection and location of temporary shelters in disaster management. J. Int. Humanit. Action 2019, 4, 16. [CrossRef]

116. Jamalul Shamsudin, N.L.; Abdul Khanan, M.F.; Umar, H.A.; Atan, S.N.; Din, A.H.M. Integrating network concept into multi criteria analysis for suggesting bus rapid transit routes. In International Archives of the Photogrammetry, Remote Sensing and Spatial Information Sciences - ISPRS Archives; Leibniz University Hannover: Hannover, Germany, 2019; pp. 309-317.

117. Song, Q.; Zilecky, P.; Jakob, M.; Hrncir, J. Exploring pareto routes in multi-criteria urban bicycle routing. In Proceedings of the 2014 17th IEEE International Conference on Intelligent Transportation Systems, Qingdao, China, 8-11 October 2014; pp. 1781-1787.

118. Derek, J.; Sikora, M. Bicycle route planning using multiple criteria GIS analysis. In Proceedings of the 2019 27th International Conference on Software, Telecommunications and Computer Networks, Split, Croatia, 19-21 September 2019.

119. Pahlavani, P.; Delavar, M.R. Multi-criteria route planning based on a driver's preferences in multi-criteria route selection. Transp. Res. Part C: Emerg. Technol. 2014, 40, 14-35. [CrossRef] 
120. Pesce, M.; Terzi, S.; Al-Jawasreh, R.I.M.; Bommarito, C.; Calgaro, L.; Fogarin, S.; Russo, E.; Marcomini, A.; Linkov, I. Selecting sustainable alternatives for cruise ships in Venice using multi-criteria decision analysis. Sci. Total Environ. 2018, 642, 668-678. [CrossRef]

121. Deveci, M.; Demirel, N.Ç.; Ahmetoğlu, E. Airline new route selection based on interval type-2 fuzzy MCDM: A case study of new route between Turkey- North American region destinations. J. Air Transp. Manag. 2017, 59, 83-99. [CrossRef]

122. Hamid-Mosaku, I.A.; Oguntade, O.F.; Ifeanyi, V.I.; Balogun, A.L.; Jimoh, O.A. Evolving a comprehensive geomatics multi-criteria evaluation index model for optimal pipeline route selection. Struct. Infrastruct. Eng. 2020, 16, 1382-1396. [CrossRef]

123. Balogun, A.L.; Matori, A.N.; Hamid-Mosaku, A.I.; Umar Lawal, D.; Ahmed Chandio, I. Fuzzy MCDM-based GIS model for subsea oil pipeline route optimization: An integrated approach. Mar. Georesources Geotechnol. 2017, 35, 961-969. [CrossRef]

124. Hamurcu, M.; Eren, T. An application of multicriteria decision-making for the evaluation of alternative monorail routes. Mathematics 2018, 7, 16. [CrossRef]

125. Saplığlu, M.; Aydın, M.M. Choosing safe and suitable bicycle routes to integrate cycling and public transport systems. J. Transp. Health 2018, 10, 236-252. [CrossRef]

126. Haial, A.; Berrado, A.; Benabbou, L. Reviewing the use of multi-criteria group decision making methods for transportation problems: Case of transport mode selection problem. In Proceedings of the International Conference on Industrial Engineering and Operations Management, Pilsen, Czech Republic, 23-26 July 2019; pp. 1275-1285.

127. Martin, J.C.; Román, C.; Moreira, P.; Moreno, R.; Oyarce, F. Does the access transport mode affect visitors' satisfaction in a World Heritage City? The case of Valparaiso, Chile. J. Transp. Geogr. 2021, 91. [CrossRef]

128. Pamucar, D.; Deveci, M.; Canitez, F.; Lukovac, V. Selecting an airport ground access mode using novel fuzzy LBWA-WASPAS-H decision making model. Eng. Appl. Artif. Intell. 2020, 93. [CrossRef]

129. Fonseca, F.; Ribeiro, P.; Jabbari, M.; Petrova, E.; Papageorgiou, G.; Conticelli, E.; Tondelli, S.; Ramos, R. Smart Pedestrian Network: An Integrated Conceptual Model for Improving Walkability. In Lecture Notes of the Institute for Computer Sciences, Social-Informatics and Telecommunications Engineering, LNICST; Springer: Berlin/Heidelberg, Germany, 2020; Volume 318, pp. 125-142.

130. Vermote, L.; Macharis, C.; Hollevoet, J.; Putman, K. Participatory evaluation of regional light rail scenarios: A Flemish case on sustainable mobility and land-use. Environ. Sci. Policy 2014, 37, 101-120. [CrossRef]

131. Lee, D.J. A multi-criteria approach for prioritizing advanced public transport modes (APTM) considering urban types in Korea. Transp. Res. Part A Policy Pract. 2018, 111, 148-161. [CrossRef]

132. Ghosh, A.; Ghorui, N.; Mondal, S.P.; Kumari, S.; Mondal, B.K.; Das, A.; Gupta, M.S. Application of Hexagonal Fuzzy MCDM Methodology for Site Selection of Electric Vehicle Charging Station. Mathematics 2021, 9, 393. [CrossRef]

133. Bac, U.; Alaloosi, K.A.M.S.; Turhan, C. A comprehensive evaluation of the most suitable HVAC system for an industrial building by using a hybrid building energy simulation and multi criteria decision making framework. J. Build. Eng. 2021, 37. [CrossRef]

134. Alhashmi, M.; Chhipi-Shrestha, G.; Ruparathna, R.; Nahiduzzaman, K.M.; Hewage, K.; Sadiq, R. Energy performance assessment framework for residential buildings in Saudi Arabia. Sustainability 2021, 13, 2232. [CrossRef]

135. Mukhamet, T.; Kobeyev, S.; Nadeem, A.; Memon, S.A. Ranking PCMs for building façade applications using multi-criteria decision-making tools combined with energy simulations. Energy 2021, 215. [CrossRef]

136. Moghtadernejad, S.; Chouinard, L.E.; Mirza, M.S. Design strategies using multi-criteria decision-making tools to enhance the performance of building façades. J. Build. Eng. 2020, 30. [CrossRef]

137. Chen, X.; Qu, K.; Calautit, J.; Ekambaram, A.; Lu, W.; Fox, C.; Gan, G.; Riffat, S. Multi-criteria assessment approach for a residential building retrofit in Norway. Energy Build. 2020, 215. [CrossRef]

138. Torabi Moghadam, S.; Lombardi, P. An interactive multi-criteria spatial decision support system for energy retrofitting of building stocks using CommuntiyVIZ to support urban energy planning. Build. Environ. 2019, 163. [CrossRef]

139. Figueira, J.; Roy, B. Determining the weights of criteria in the ELECTRE type methods with a revised Simos' procedure. Eur. J. Oper. Res. 2002, 139, 317-326. [CrossRef]

140. Lassandro, P.; Di Turi, S. Multi-criteria and multiscale assessment of building envelope response-ability to rising heat waves. Sustain. Cities Soc. 2019, 51. [CrossRef]

141. Wang, L.; Ma, G.; Zhou, F.; Liu, Y.; Tian, T. Multicriteria decision-making approach for selecting ventilation heat recovery devices based on the attributes of buildings and the preferences of decision makers. Sustain. Cities Soc. 2019, 51. [CrossRef]

142. Noori, A.; Bonakdari, H.; Morovati, K.; Gharabaghi, B. Development of optimal water supply plan using integrated fuzzy Delphi and fuzzy ELECTRE III methods-Case study of the Gamasiab basin. Expert Syst. 2020, 37. [CrossRef]

143. Gebre, S.L.; Cattrysse, D.; Van Orshoven, J. Multi-criteria decision-making methods to address water allocation problems: A systematic review. Water 2021, 13, 125. [CrossRef]

144. Whitley, D. A genetic algorithm tutorial. Stat. Comput. 1994, 4, 65-85. [CrossRef]

145. Savun-Hekimoğlu, B.; Erbay, B.; Hekimoğlu, M.; Burak, S. Evaluation of water supply alternatives for Istanbul using forecasting and multi-criteria decision making methods. J. Clean. Prod. 2021, 287. [CrossRef]

146. Noori, A.; Bonakdari, H.; Salimi, A.H.; Gharabaghi, B. A group Multi-Criteria Decision-Making method for water supply choice optimization. Socio-Econ. Plan. Sci. 2021. [CrossRef]

147. Singh, L.K.; Jha, M.K.; Chowdary, V.M. Planning rainwater conservation measures using geospatial and multi-criteria decision making tools. Environ. Sci. Pollut. Res. 2021, 28, 1734-1751. [CrossRef] 
148. Quinn, R.; Rougé, C.; Stovin, V. Quantifying the performance of dual-use rainwater harvesting systems. Water Res. X 2021, 10. [CrossRef]

149. Machado, V.C.; Lafuente, J.; Baeza, J.A. Systematic comparison framework for selecting the best retrofitting alternative for an existing water resource recovery facility. Water Environ. Res. 2020, 92, 2072-2085. [CrossRef]

150. Forgy, E. Cluster analysis of multivariate data: Efficiency versus interpretability of classifications. Biometrics 1965, $21,768-769$.

151. Brentan, B.M.; Carpitella, S.; Izquierdo, J.; Luvizotto, E.; Meirelles, G. District metered area design through multicriteria and multiobjective optimization. Math. Methods Appl. Sci. 2021. [CrossRef]

152. Ashofteh, P.S.; Golfam, P.; Loáiciga, H.A. Evaluation of River Water Transfer Alternatives with the TODIM Multi-Criteria Decision Making Method. Water Resour. Manag. 2020, 34, 4847-4863. [CrossRef]

153. Narayanamoorthy, S.; Annapoorani, V.; Kalaiselvan, S.; Kang, D. Hybrid hesitant fuzzy multi-criteria decision making method: A symmetric analysis of the selection of the best water distribution system. Symmetry 2020, 12, 2096. [CrossRef]

154. Cunha, M.; Marques, J.; Savić, D. A Flexible Approach for the Reinforcement of Water Networks Using Multi-Criteria Decision Analysis. Water Resour. Manag. 2020, 34, 4469-4490. [CrossRef]

155. Fathi, S.; Hagen, J.S.; Haidari, A.H. Synthesizing existing frameworks to identify the potential for Managed Aquifer Recharge in a karstic and semi-arid region using GIS Multi Criteria Decision Analysis. Groundw. Sustain. Dev. 2020, 11. [CrossRef]

156. Rubio-Aliaga, A.; García-Cascales, M.S.; Sánchez-Lozano, J.M.; Molina-Garcia, A. MCDM-based multidimensional approach for selection of optimal groundwater pumping systems: Design and case example. Renew. Energy 2021, 163, 213-224. [CrossRef]

157. Sadr, S.M.K.; Johns, M.B.; Memon, F.A.; Duncan, A.P.; Gordon, J.; Gibson, R.; Chang, H.J.F.; Morley, M.S.; Savic, D.; Butler, D. Development and application of a multi-objective-optimization and multi-criteria-based decision support tool for selecting optimal water treatment technologies in india. Water 2020, 12, 2836. [CrossRef]

158. Maleki, H.; Zahir, S. A Comprehensive Literature Review of the Rank Reversal Phenomenon in the Analytic Hierarchy Process. J. Multi-Criteria Decis. Anal. 2013, 20, 141-155. [CrossRef]

159. Aires, R.F.d.F.; Ferreira, L. The rank reversal problem in multi-criteria decision making: A literature review. Pesqui. Oper. 2018, 38, 331-362. [CrossRef]

160. Chi, H.-L.; Wang, X.; Jiao, Y. BIM-Enabled Structural Design: Impacts and Future Developments in Structural Modelling, Analysis and Optimisation Processes. Arch. Comput. Methods Eng. 2015, 22, 135-151. [CrossRef]

161. Mardani, A.; Jusoh, A.; Md Nor, K.; Khalifah, Z.; Zakwan, N.; Valipour, A. Multiple criteria decision-making techniques and their applications-A review of the literature from 2000 to 2014. Econ. Res. Ekon. Istraživanja 2015, 28, 516-571. [CrossRef]

162. Mustajoki, J.; Hämäläinen, R.P. Web-Hipre: Global Decision Support By Value Tree And AHP Analysis. Infor: Inf. Syst. Oper. Res. 2000, 38, 208-220. [CrossRef]

163. Cinelli, M.; Spada, M.; Kim, W.; Zhang, Y.; Burgherr, P. MCDA Index Tool: An interactive software to develop indices and rankings. Environ. Syst. Decis. 2020. [CrossRef] [PubMed]

164. Yadav, V.; Karmakar, S.; Kalbar, P.P.; Dikshit, A.K. PyTOPS: A Python based tool for TOPSIS. SoftwareX 2019, 9, 217-222. [CrossRef]

165. Rezaei, J. A Concentration Ratio for Nonlinear Best Worst Method. Int. J. Inf. Technol. Decis. Mak. 2020, 19, 891-907. [CrossRef] 